\title{
Inventário dos grupos brasileiros de pesquisa na teoria histórico-cultural a partir do Diretório de Grupos do $\mathrm{CNPq}^{1}$
}

\author{
Inventory of Brazilian research groups \\ in historical-cultural theory \\ from the Diretório de Grupos/CNPq
}

Flávia da Silva Ferreira Asbahr ${ }^{2}$

Miriam Lais Setti de Almeida Marcelo Oliveira ${ }^{3}$

\begin{abstract}
RESUMO
Este documento visa apresentar uma lista dos 115 grupos de pesquisa localizados na investigação intitulada "A Psicologia Histórico-Cultural na pesquisa brasileira: levantamento dos grupos de pesquisa cadastrados no diretório do CNPq". A pesquisa teve como objetivo geral investigar a inserção da Psicologia Histórico-Cultural ou Teoria Histórico-Cultural no âmbito da investigação científica no Brasil, em grupos de pesquisa que a indicam formalmente como norteadora para os trabalhos. Um de nossos objetivos específicos, cujo resultado consta neste documento, foi identificar grupos de pesquisa cadastrados no Diretório de Grupos de Pesquisa do Conselho Nacional de Desenvolvimento Científico e
\end{abstract}

\begin{abstract}
This document aims to present a list of 115 research groups located in the investigation entitled "Historical-Cultural Psychology in Brazilian research: survey of research groups registered in the CNPq directory". The general objective of the research was to investigate the insertion of Historical-Cultural Psychology or Historical-Cultural Theory within the scope of scientific research in Brazil, in research groups that formally indicate it as guiding the work. One of our specific objectives, the result of which is contained in this document, was to identify research groups registered in the Research Diretório de Grupos de Pesquisa do Conselho Nacional de Desenvolvimento Científico e Tecnológico (DGP-CNPq) that pointed to Psychology or Historical-Cultural
\end{abstract}

\footnotetext{
${ }^{1}$ A pesquisa contou com financiamento da Fundação de Amparo à Pesquisa do Estado de São Paulo (FAPESP: 2017/21936-5).

2 Psicóloga. Mestre e Doutora em Psicologia pelo IPUSP. Docente do Departamento de Psicologia e do Programa de pós-graduação em Psicologia do Desenvolvimento e Aprendizagem - Faculdade de Ciências - UNESP/Bauru, Brasil. Orcid: https://orcid.org/0000-0002-7338-0003. E-mail: flavia.asbahr@unesp.br.

${ }^{3}$ Psicóloga. Foi bolsista de Treinamento Técnico I (FAPESP) do projeto de pesquisa que dá origem a este documento. Residente em Saúde Mental na Prefeitura Municipal de Sorocaba, PM/Sorocaba, Brasil. Bolsista do Ministério da Economia, Ministério da Economia, Brasil. Orcid: https://orcid.org/0000-0001-5470-6672. E-mail: miriamsetti.psi@gmail.com.
} 
Tecnológico (DGP-CNPq) que apontassem a Psicologia ou Teoria Histórico-Cultural como referencial teórico assumido. Entende-se que a apresentação do resultado bruto de pesquisa, ou seja, quais foram os 115 grupos localizados, pode constituir-se em importante fonte para outras investigações sobre a Teoria Histórico-Cultural no Brasil, bem como facilitar o intercâmbio e a divulgação científica entre grupos.

Palavras-chave: Teoria histórico-cultural. Psicologia histórico-cultural. Grupos de Pesquisa. Diretório de grupos de pesquisa do CNPq.
Theory as an assumed theoretical reference. It is understood that the presentation of the gross research result, which were the 115 groups located, can constitute an important source for other investigations on the Historical-Cultural Theory in Brazil, as well as facilitating scientific exchange and dissemination between groups.

Keywords: Historical-cultural theory. Research Groups. Historical-Cultural Psychology. Diretório de grupos de pesquisa do CNPq.

\section{Introdução}

Este documento visa apresentar uma lista dos grupos de pesquisa localizados na investigação intitulada "A Psicologia Histórico-Cultural na pesquisa brasileira: levantamento dos grupos de pesquisa cadastrados no diretório do CNPq", coordenada por Flávia da Silva Ferreira Asbahr, com financiamento da Fundação de Amparo à Pesquisa do Estado de São Paulo (FAPESP: 2017/21936-5) .

A pesquisa teve como objetivo geral investigar a inserção da Psicologia Histórico-Cultural ou Teoria Histórico-Cultural no âmbito da investigação científica no Brasil, em grupos de pesquisa que a indicam formalmente como norteadora para os trabalhos.

Um de nossos objetivos específicos, cujo resultado consta neste documento, foi identificar grupos de pesquisa cadastrados no Diretório de Grupos de Pesquisa do Conselho Nacional de Desenvolvimento Científico e Tecnológico (DGP-CNPq) que apontassem a Psicologia ou Teoria HistóricoCultural como referencial teórico assumido.

\footnotetext{
${ }^{4}$ A pesquisa, com diferentes frentes de análise depois do levantamento dos dados, teve a seguinte equipe de pesquisa: Pesquisadoras: Flávia da Silva Ferreira Asbahr (Unesp-Bauru); Marilene Proença Rebello de Souza (Docente IPUSP) e Sonia Maria Shima Barroco (Docente do curso de Psicologia da UEM). Estudantes envolvidos: Marília Alves dos Santos (mestranda- FC/UnespBauru), Jéssica Clemente (mestranda-UEM), Miriam Laís Setti de Almeida Marcelo Oliveira (Estudante de Psicologia-Unesp-Bolsa Fapesp TT1), Ingrid Bueno Alves (Estudante de PsicologiaUSP-Bolsa IC CNPq), Renato Libarino Aguilar (Estudante de Psicologia-USP-Bolsa IC CNPq), Alexia Oliveira Silva (Estudante de Psicologia-USP-Bolsa IC CNPq).
} 
Entende-se que a apresentação do resultado bruto de pesquisa, ou seja, quais foram os grupos localizados, pode constituir-se em importante fonte para outras investigações sobre a Teoria Histórico-Cultural no Brasil, bem como facilitar o intercâmbio e a divulgação científica entre grupos.

Para atingir os objetivos de pesquisa foi realizado um estudo do tipo "estado da arte" ou "estado do conhecimento" (FERREIRA, 2000). A escolha do Diretório de Grupos de Pesquisa do CNPq como fonte justifica-se pela própria natureza desta ferramenta: "constitui-se no inventário dos grupos de pesquisa científica e tecnológica em atividade no país" (Informação disponível em http://lattes.cnpq.br/web/dgp/o-que-e/ - acesso em 26/06/19).

\section{Metodologia de levantamento de dados}

Foi realizada uma coleta de dados com base nas informações contidas no site do DGP-CNPq. A consulta on line inicial foi realizada no endereço http://dgp.cnpq.br/dgp/faces/consulta/consulta_parametrizada.jsf, e foi feita em dois momentos: 1) entre maio e junho de 2018, em que foram localizados 98 grupos ${ }^{5}$; 2) entre novembro e dezembro de $2018^{6}$, quando o levantamento foi conferido, ampliado e incluiu-se novos descritores de busca, totalizando uma amostra de 115 grupos.

No primeiro momento utilizou-se as seguintes palavras-chave: Teoria Histórico-Cultural; Psicologia Histórico-Cultural; Psicologia Sócio-Histórica(o); Escola de Vigotski; Escola de Vygotsky; Escola de Vygotski; Teoria da Atividade; Psicologia Soviética; Teoria Sócio-Cultural; Teoria SócioHistórica(o). Justifica-se a eleição destas palavras-chave pelo emprego das mesmas pelos próprios autores soviéticos ou pelo uso consensual atual dos pesquisadores da área. Ao longo da pesquisa, foram acrescentados outros termos: abordagem histórico-cultural; perspectiva histórico-cultural; psicologia e marxismo; teoria da subjetividade; enfoque sócio-histórico.

\footnotetext{
${ }^{5}$ Este primeiro levantamento foi realizado por Miriam Laís Setti de Almeida Marcelo Oliveira, na época estudante de psicologia da UNESP-Bauru, bolsista Treinamento Técnico da Fapesp (TT-1). ${ }^{6}$ Este segundo levantamento foi feito por Ingrid Bueno Alves e Renato Libarino Aguilar (ambos alunos de Psicologia, do Instituto de Psicologia, Universidade de São Paulo), bolsistas de IC pelo CNPq.
} 
Após levantamento no Diretório dos Grupos de Pesquisa do CNPq, de acordo com as palavras-chave previamente selecionadas e após a leitura da descrição das páginas dos grupos selecionados contidas na base corrente do Diretório de Grupos de Pesquisa do $\mathrm{CNPq}$, bem como nas linhas de pesquisa descritas e Currículo Lattes de seus líderes ${ }^{7}$, foram considerados para análise, 115 grupos de pesquisa brasileiros cujo referencial teórico é Teoria Histórico-Cultural, com suas diferentes nomeações.

É importante destacar que os grupos aqui apresentados foram localizados e incluídos na amostra se usaram as palavras-chave mencionadas em seu nome, descrição do grupo e/ou linha de pesquisa. Sabemos que provavelmente há outros grupos que se embasam na perspectiva teórica em foco, mas que não utilizam as palavras-chaves definidas por nós e, assim, não puderem ser localizados no DGP$\mathrm{CNPq}$ e incluídos na amostra. Os grupos que estavam excluídos ou com pendências de preenchimento no diretório no período do levantamento também não puderam ser incluídos na amostra, pois não podem ser localizados pelas ferramentas de busca do próprio DGP-CNPq.

Outra dificuldade para encontrar os grupos foi a própria instabilidade do site do DGP-CNPq que ficou fora do ar durante parte considerável da pesquisa, ou seja, de novembro de 2018 até junho de 2019, quando estávamos conferindo as informações. Ou mesmo a discrepância de dados a depender do momento em que o site era acessado, por exemplo, um grupo encontrado em determinado momento não era mais localizado um tempo depois ${ }^{8}$. As ferramentas de busca funcionaram bem no início da pesquisa em 2018, mas atualmente os dados de alguns grupos são difíceis de encontrar, mesmo com grupo em atividade. Avaliamos que o diretório de grupos de pesquisa do $\mathrm{CNPq}$ é uma ferramenta fundamental à pesquisa brasileira e sabemos que poucos países têm uma plataforma em que é possível acessar com facilidade os grupos de pesquisa existentes e o currículo de seus pesquisadores (em

\footnotetext{
${ }^{7} \mathrm{O}$ currículo lattes do líder do grupo foi consultado quando, na descrição do grupo, não tínhamos certeza se a teoria histórico-cultural era o referente teórico do grupo.

8 Ao percebermos estas instabilidades anotamos como estratégia imprimir as páginas com descrição dos grupos de forma a ter acesso aos dados a qualquer momento.
} 
nosso caso, via Currículo Lattes). Avaliamos que a instabilidade do diretório com a qual nos deparamos é extremamente prejudicial à pesquisa nacional. No início do levantamento, por exemplo, os estudantes de IC vinculados à pesquisa fizeram o levantamento de grupos usando as mesmas palavraschaves e o número encontrado por eles não foi coincidente, o que nos exigiu o cotejamento de todas as informações levantadas para chegarmos à amostra de 115 grupos. Mesmo assim alertamos que há grupos que podem não ter aparecido em nosso levantamento, o que exigirá atualizações futuras.

Dos 115 grupos foram extraídas as seguintes informações: termos usados para nomear a PHC; áreas de conhecimento de vinculação dos Grupos; distribuição geográfica dos Grupos; natureza da instituição a qual o Grupo se insere; ano de formação dos Grupos; vinculação à PPGs e referência ao materialismo histórico-dialético. Estes dados permitem uma panorâmica geral quantitativa sobre os grupos, objeto de investigação. Em um segundo momento, buscamos mapear quais são os principais temas de estudo e pesquisa de nossos grupos. Finalmente, em um terceiro momento, foram escolhidos alguns dos temas de pesquisa categorizados por nós e foram feitas análises da produção dos grupos por recorte temático ${ }^{9}$, buscando as produções de líderes e vice-líderes, de modo a iniciar discussões de possíveis desdobramentos ou tendências de adoção deste referencial teórico em áreas do conhecimento em que a Psicologia Histórico-Cultural é mais frequente.

Foge aos limites deste documento apresentar a análise pormenorizada dos $\operatorname{dados}^{10}$, mas gostaríamos, antes de apresentar a lista dos grupos localizados, apresentar algumas informações gerais sobre os grupos.

\section{Algumas informações gerais sobre os grupos}

\footnotetext{
9 Foram feitos, até o momento, os seguintes recortes temáticos: Formação docente continuada (Santos, 2020); Processos saúde-doença (OLIVEIRA \& ASBAHR, 2018); Produção da queixa escolar (GUARAGNA, 2020); Políticas Públicas em educação (SILVA, 2021); Educação Especial (CLEMENTE, 2020).

10 Um artigo com a análise completa dos dados foi recentemente submetido a outro periódico científico, mas dados preliminares podem ser vistos em Asbahr (2019) e em Toassa, Asbahr e Souza (2020).
} 
De forma a termos um breve panorama geral sobre os grupos de pesquisa apresentam-se os dados sobre suas principais áreas de conhecimento, sobre sua distribuição geográfica e sobre a natureza da instituição a qual estão vinculados.

No que se refere às estas áreas de conhecimento ${ }^{11}$, verificou-se qual era a grande área e a área específica de concentração dos grupos elencados. Há uma predominante distribuição na grande área de Ciências Humanas, nas áreas específicas de Educação, que concentra a maioria dos grupos de pesquisa mapeados, 58,26\%, abarcando 67 grupos, e na área de Psicologia que corresponde a $\mathbf{3 2 , 1 7 \%}$, com 37 grupos. As demais áreas do conhecimento representam uma pequena proporção.

Sobre a distribuição geográfica dos grupos de pesquisa, a maioria localizase nas regiões sudeste, com a maior quantidade de grupos, e sul ( $2^{\mathrm{a}}$ maior quantidade de grupos), confirmando a desigualdade regional do desenvolvimento da pesquisa no país. A região nordeste encontra-se como a terceira em número de grupos de pesquisa, seguida pela região centro-oeste e pela região norte.

Por último, gostaríamos de destacar a natureza das Instituições de Ensino Superior (IES) as quais estão vinculados os grupos de pesquisa: públicas, podendo ser instituições municipais, estaduais e federais; e privadas, incluindo-se aqui as instituições particulares confessionais. A análise da distribuição dos grupos de pesquisa de acordo com o tipo de instituição de ensino superior às quais pertencem, aponta a maior concentração em Universidades Públicas como lócus centrais de pesquisa em nosso país (88,8\% dos grupos), bem como local de formação de pesquisadores, como vemos na figura abaixo:

\footnotetext{
11 Usamos como referência o item "Área predominante" presente na descrição dos grupos no DGP, que segue a classificação de áreas do conhecimento disponível em:

http://lattes.cnpq.br/documents/11871/24930/TabeladeAreasdoConhecimento.pdf/d192ff6b-3e0a-4074a $74 d-c 280521 b d 5 f 7$.
} 
Gráfico - Distribuição dos Grupos de Pesquisa Cadastrados no CNPq de Acordo com a natureza da IES à qual pertencem

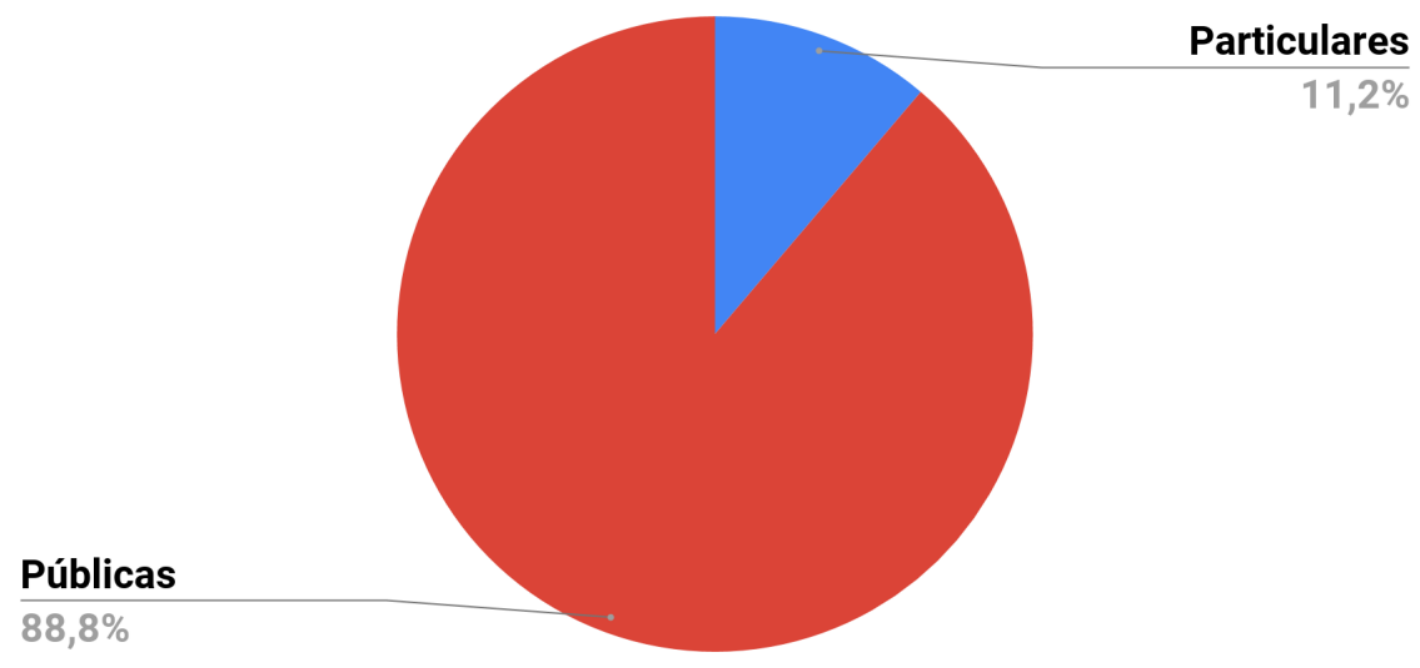

Fonte: Elaborado pelas autoras.

\section{Grupos de pesquisa localizados}

No quadro abaixo apresentaremos os 115 grupos de pesquisa localizados, destacando seu nome, líderes, instituição de origem e link para o espelho do grupo no DGP-CNPq e área predominante. Também dividimos os grupos por região geográfica ${ }^{12}$ de forma a facilitar a localização por futuros pesquisadores e para que se possa ter um panorama regional. Ao preparar o documento verificamos que muitos dos grupos levantados em 2018 encontram-se, neste momento (maio/2021), com status de grupo excluído ou em preenchimento, provavelmente pela falta de atualização dos dados. Há alguns poucos grupos que não puderam ser localizados, o que é informado no próprio quadro. Como tivemos o cuidado de imprimir todas as descrições dos grupos, pudemos recuperar o espelho (link de acesso) dos grupos e é possível reaver suas informações, mesmo

\footnotetext{
12 Usamos como critério de distribuição geográfica as cinco grandes regiões definidas pelo IBGE: Região Norte, Região Nordeste, Região Centro-Oeste, Região Sudeste e Região Sul (informações disponíveis em https://educa.ibge.gov.br/). Nas tabelas abaixo são apresentadas os grupos por região seguindo uma ordem decrescente de números de grupo.
} 
quando estão desativados no DGP-CNPq. Grupos criados a partir de 2019 não

fizeram parte de nossa amostra, pois fizemos a coleta até dezembro de 2018.

Esperamos que os dados brutos abaixo apresentados em ordem alfabética possam servir de material para outras pesquisas sobre a extensão da teoria histórico-cultural no Brasil, com suas diferentes nomeações.

Tabela - Lista dos grupos por região e em ordem alfabética

\begin{tabular}{|c|c|c|c|c|}
\hline $\begin{array}{l}\text { Nome do grupo } \\
\text { de pesquisa }\end{array}$ & $\begin{array}{l}\text { Líder(es) do } \\
\text { grupo: }\end{array}$ & $\begin{array}{c}\text { Instituição de } \\
\text { origem }\end{array}$ & Espelho do grupo & $\begin{array}{c}\text { Área } \\
\text { predominante }\end{array}$ \\
\hline \multicolumn{5}{|c|}{ REGIÃO SUDESTE } \\
\hline $\begin{array}{l}\text { Abordagem } \\
\text { histórico- } \\
\text { cultural, } \\
\text { oralidade e } \\
\text { práticas sociais }\end{array}$ & $\begin{array}{l}\text { Luiza } \\
\text { Rodrigues de } \\
\text { Oliveira e Rose } \\
\text { Mary Latini }\end{array}$ & $\begin{array}{l}\text { Universidade } \\
\text { Federal } \\
\text { Fluminense - } \\
\text { UFF }\end{array}$ & $\begin{array}{l}\text { http://dgp.cnpq.br/dgp/espelh } \\
\underline{\text { ogrupo/4765722506719269 }}\end{array}$ & Psicologia \\
\hline $\begin{array}{l}\text { A perspectiva } \\
\text { sócio-histórico } \\
\text { cultural e da } \\
\text { atividade e } \\
\text { o ensino- } \\
\text { aprendizagem } \\
\text { de língua } \\
\text { estrangeira }\end{array}$ & $\begin{array}{l}\text { Marília Mendes } \\
\text { Ferreira }\end{array}$ & $\begin{array}{l}\text { Universidade } \\
\text { de São Paulo - } \\
\text { USP }\end{array}$ & $\begin{array}{l}\text { http://dgp.cnpq.br/dgp/espelh } \\
\text { ogrupo/4012969521480254 }\end{array}$ & Linguística \\
\hline $\begin{array}{l}\text { Análise e } \\
\text { prevenção de } \\
\text { riscos } \\
\text { relacionados ao } \\
\text { trabalho }\end{array}$ & $\begin{array}{l}\text { Rodolfo } \\
\text { Andrade de } \\
\text { Gouveia Vilela } \\
\text { Ildeberto Muniz } \\
\text { de Almeida }\end{array}$ & $\begin{array}{l}\text { Universidade } \\
\text { de São Paulo- } \\
\text { SP }\end{array}$ & $\begin{array}{l}\text { http://dgp.cnpq.br/dgp/espelh } \\
\underline{\text { ogrupo/0362833960809812 }}\end{array}$ & Saúde coletiva \\
\hline $\begin{array}{l}\text { Atividade } \\
\text { docente e } \\
\text { Subjetividade }\end{array}$ & $\begin{array}{l}\text { Wanda Maria } \\
\text { Jungueira } \\
\text { Aguiar } \\
\text { Claudia Leme } \\
\text { Ferreira Davis }\end{array}$ & $\begin{array}{l}\text { Pontifícia } \\
\text { Universidade } \\
\text { Católica de São } \\
\text { Paulo - } \\
\text { PUC/SP }\end{array}$ & $\begin{array}{l}\text { http://dgp.cnpq.br/dgp/espelh } \\
\underline{\text { ogrupo/5419396065174800 }}\end{array}$ & Educação \\
\hline $\begin{array}{l}\text { CHOICES - } \\
\text { Culture and } \\
\text { Historicity in } \\
\text { Out-of-School } \\
\text { Innovations for } \\
\text { Communication } \\
\text { and Education } \\
\text { in Science }\end{array}$ & $\begin{array}{l}\text { Alessandra } \\
\text { Fernandes } \\
\text { Bizerra }\end{array}$ & $\begin{array}{l}\text { Universidade } \\
\text { de São Paulo - } \\
\text { USP }\end{array}$ & $\begin{array}{l}\text { http://dgp.cnpq.br/dgp/espelh } \\
\underline{\text { ogrupo/8575628784624400 }}\end{array}$ & Educação \\
\hline $\begin{array}{l}\text { Educação, } \\
\text { Sociedade e } \\
\text { Políticas } \\
\text { Públicas: } \\
\text { concepções da } \\
\text { teoria histórico- } \\
\text { cultural }\end{array}$ & $\begin{array}{l}\text { Maria Eliza } \\
\text { Mattozinho } \\
\text { Bernardes }\end{array}$ & $\begin{array}{l}\text { Universidade } \\
\text { de São Paulo - } \\
\text { USP }\end{array}$ & $\begin{array}{l}\text { http://dgp.cnpq.br/dgp/espelh } \\
\text { ogrupo/7182297325228611 }\end{array}$ & Educação \\
\hline $\begin{array}{l}\text { EPSEC } \\
\text { Epistemologia } \\
\text { e Psicologia no } \\
\text { Ensino de } \\
\text { Ciências }\end{array}$ & $\begin{array}{l}\text { Joana de Jesus } \\
\text { de Andrade }\end{array}$ & $\begin{array}{l}\text { Universidade } \\
\text { de São Paulo - } \\
\text { USP }\end{array}$ & $\begin{array}{l}\text { http://dgp.cnpq.br/dgp/espelh } \\
\underline{\text { ogrupo/6050965093787146 }}\end{array}$ & Educação \\
\hline
\end{tabular}




\begin{tabular}{|c|c|c|c|c|}
\hline $\begin{array}{l}\text { Estudos e } \\
\text { Pesquisa em } \\
\text { Trabalho e } \\
\text { Ação Social } \\
\text { (NUTAS) }\end{array}$ & Odair Furtado & $\begin{array}{l}\text { Pontifícia } \\
\text { Universidade } \\
\text { Católica de São } \\
\text { Paulo - PUC/SP }\end{array}$ & $\begin{array}{l}\text { http://dgp.cnpq.br/dgp/espelh } \\
\underline{\text { ogrupo/0686910526870015 }}\end{array}$ & Psicologia \\
\hline $\begin{array}{l}\text { GEDHEE - } \\
\text { Grupo de } \\
\text { Estudos em } \\
\text { Desenvolviment } \\
\text { o Humano e } \\
\text { Educação } \\
\text { Escolar - } \\
\text { Pedagogia } \\
\text { Histórico-crítica } \\
\text { e Psicologia } \\
\text { Histórico- } \\
\text { cultural }\end{array}$ & $\begin{array}{l}\text { Rosiane de } \\
\text { Fátima Ponce e } \\
\text { Renata Maria } \\
\text { Coimbra }\end{array}$ & $\begin{array}{l}\text { Universidade } \\
\text { Estadual } \\
\text { Paulista Júlio } \\
\text { de Mesquita } \\
\text { Filho - UNESP }\end{array}$ & $\begin{array}{l}\text { http://dgp.cnpq.br/dgp/espelh } \\
\text { ogrupo/8483713936654357 }\end{array}$ & Educação \\
\hline $\begin{array}{l}\text { GEPEDEI - } \\
\text { Grupo de } \\
\text { Estudos e de } \\
\text { Pesquisa em } \\
\text { Especificidades } \\
\text { da Docência na } \\
\text { Educação } \\
\text { Infantil }\end{array}$ & $\begin{array}{l}\text { Elieuza } \\
\text { Aparecida de } \\
\text { Lima }\end{array}$ & $\begin{array}{l}\text { Universidade } \\
\text { Estadual } \\
\text { Paulista - } \\
\text { UNESP }\end{array}$ & $\begin{array}{l}\text { http://dgp.cnpq.br/dgp/espelh } \\
\text { ogrupo/2086805060875094 }\end{array}$ & Educação \\
\hline $\begin{array}{l}\text { GEPEDI - } \\
\text { Grupo de } \\
\text { Estudos e } \\
\text { Pesquisas em } \\
\text { Didática } \\
\text { Desenvolvimen } \\
\text { tal e } \\
\text { profissionaliza } \\
\text { ção docente }\end{array}$ & $\begin{array}{l}\text { Roberto Valdés } \\
\text { Puentes e } \\
\text { Andréa } \\
\text { Maturano } \\
\text { Longarezi }\end{array}$ & $\begin{array}{l}\text { Universidade } \\
\text { Federal de } \\
\text { Uberlândia - } \\
\text { UFU }\end{array}$ & $\begin{array}{l}\text { http://dgp.cnpq.br/dgp/espelh } \\
\text { ogrupo/8035910316278302 }\end{array}$ & Educação \\
\hline $\begin{array}{l}\text { GEPEMAPe - } \\
\text { Grupo de } \\
\text { estudos e } \\
\text { pesquisa em } \\
\text { ensino de } \\
\text { Matemática e } \\
\text { atividade } \\
\text { pedagógica }\end{array}$ & $\begin{array}{l}\text { Fabiana Fiorezi } \\
\text { de Marco e } \\
\text { Maria Teresa } \\
\text { Menezes } \\
\text { Freitas }\end{array}$ & $\begin{array}{l}\text { Universidade } \\
\text { Federal de } \\
\text { Uberlândia - } \\
\text { UFU }\end{array}$ & $\begin{array}{l}\text { http://dgp.cnpq.br/dgp/espelh } \\
\text { ogrupo/180219 }\end{array}$ & Educação \\
\hline $\begin{array}{l}\text { Grupo de } \\
\text { Estudos e } \\
\text { Pesquisas em } \\
\text { Fundamentos } \\
\text { da Educação } \\
\text { Especial }\end{array}$ & $\begin{array}{l}\text { Douglas } \\
\text { Christian } \\
\text { Ferrari de Melo } \\
\text { e Eliesér } \\
\text { Toretta Zen }\end{array}$ & $\begin{array}{l}\text { Universidade } \\
\text { Federal do } \\
\text { Espírito Santo - } \\
\text { UFES }\end{array}$ & $\begin{array}{l}\text { http://dgp.cnpq.br/dgp/espelh } \\
\text { ogrupo/4537368565174961 }\end{array}$ & Educação \\
\hline $\begin{array}{l}\text { Grupo de } \\
\text { Estudos e } \\
\text { Pesquisa do } \\
\text { Ensino e } \\
\text { Aprendizagem } \\
\text { da Matemática } \\
\text { na Infância }\end{array}$ & $\begin{array}{l}\text { Elaine Sampaio } \\
\text { Araujo e Ana } \\
\text { Paula Gladcheff } \\
\text { Munhoz }\end{array}$ & $\begin{array}{l}\text { Universidade } \\
\text { de São Paulo - } \\
\text { USP }\end{array}$ & $\begin{array}{l}\text { http://dgp.cnpq.br/dgp/espelh } \\
\text { ogrupo/0391523134313918 }\end{array}$ & Educação \\
\hline $\begin{array}{l}\text { Grupo de } \\
\text { Estudos e } \\
\text { Pesquisa em } \\
\text { Educação } \\
\text { Infantil e Teoria } \\
\text { Histórico- }\end{array}$ & $\begin{array}{l}\text { Eliza Maria } \\
\text { Barbosa e } \\
\text { Francisco José } \\
\text { Carvalho } \\
\text { Mazzeu }\end{array}$ & $\begin{array}{l}\text { Universidade } \\
\text { Estadual } \\
\text { Paulista Julio } \\
\text { de Mesquita } \\
\text { Filho - UNESP }\end{array}$ & $\begin{array}{l}\text { http://dgp.cnpq.br/dgp/espelh } \\
\underline{\text { ogrupo/1532557334928001 }}\end{array}$ & Educação \\
\hline
\end{tabular}




\begin{tabular}{|c|c|c|c|c|}
\hline Cultural & & & & \\
\hline $\begin{array}{l}\text { Grupo de } \\
\text { Estudos e } \\
\text { Pesquisa em } \\
\text { Processos } \\
\text { Educativos e } \\
\text { Perspectiva } \\
\text { Histórico- } \\
\text { Cultural } \\
\text { (GEPPEDH) }\end{array}$ & $\begin{array}{l}\text { Vanessa Dias } \\
\text { Moretti e Edna } \\
\text { Martins }\end{array}$ & $\begin{array}{l}\text { Universidade } \\
\text { Federal de São } \\
\text { Paulo - } \\
\text { UNIFESP }\end{array}$ & $\begin{array}{l}\text { http://dgp.cnpq.br/dgp/espelh } \\
\underline{\text { ogrupo/2746415536287693 }}\end{array}$ & Educação \\
\hline $\begin{array}{l}\text { Grupo de } \\
\text { Estudos e } \\
\text { pesquisa em } \\
\text { Psicologia } \\
\text { Histórico- } \\
\text { cultural na } \\
\text { Sala de Aula } \\
\text { (GEPSA) }\end{array}$ & $\begin{array}{l}\text { Maria de } \\
\text { Fátima Cardoso } \\
\text { Gomes e } \\
\text { Vanessa Ferraz } \\
\text { Almeida Neves }\end{array}$ & $\begin{array}{l}\text { Universidade } \\
\text { Federal de } \\
\text { Minas Gerais - } \\
\text { UFMG }\end{array}$ & $\begin{array}{l}\text { http://dgp.cnpq.br/dgp/espelh } \\
\underline{\text { ogrupo/8539807347932482 }}\end{array}$ & Educação \\
\hline $\begin{array}{l}\text { Grupo de } \\
\text { estudos e } \\
\text { pesquisa sobre } \\
\text { atividade } \\
\text { pedagógica }\end{array}$ & $\begin{array}{l}\text { Manoel } \\
\text { Oriosvaldo de } \\
\text { Moura e Elaine } \\
\text { Sampaio Araújo }\end{array}$ & $\begin{array}{l}\text { Universidade } \\
\text { de São Paulo - } \\
\text { USP }\end{array}$ & $\begin{array}{l}\text { http://dgp.cnpq.br/dgp/espelh } \\
\underline{\text { ogrupo/1737194701444929 }}\end{array}$ & Educação \\
\hline $\begin{array}{l}\text { Grupo de } \\
\text { Estudos e } \\
\text { Pesquisas em } \\
\text { Aprendizagem, } \\
\text { Desenvolvimen } \\
\text { to humano e } \\
\text { Escolarização }\end{array}$ & $\begin{array}{l}\text { Fernanda } \\
\text { Vilhena Mafra } \\
\text { Bazon e } \\
\text { Daniele Lozano }\end{array}$ & $\begin{array}{l}\text { Universidade } \\
\text { Federal de São } \\
\text { Carlos - } \\
\text { UFSCAR }\end{array}$ & $\begin{array}{l}\text { http://dgp.cnpq.br/dgp/espelh } \\
\underline{\text { ogrupo/4531495299068276 }}\end{array}$ & Educação \\
\hline $\begin{array}{l}\text { Grupo de } \\
\text { Estudos e } \\
\text { Pesquisas } \\
\text { Psicologia da } \\
\text { aprendizagem } \\
\text { no âmbito } \\
\text { Histórico- } \\
\text { Cultural: } \\
\text { linguagem, } \\
\text { pensamento e } \\
\text { desenvolviment } \\
\text { o na } \\
\text { perspectiva de } \\
\text { Vygotsky } \\
\text { (GPVY) }\end{array}$ & $\begin{array}{l}\text { Ademar Dias de } \\
\text { Oliveira }\end{array}$ & $\begin{array}{l}\text { União das } \\
\text { Instituições de } \\
\text { Serviço, Ensino } \\
\text { e Pesquisa - } \\
\text { UNISEPE } \\
\text { Registro-SP }\end{array}$ & $\begin{array}{l}\text { http://dgp.cnpq.br/dgp/espelh } \\
\underline{\text { ogrupo/1398609199446041 }}\end{array}$ & Psicologia \\
\hline $\begin{array}{l}\text { Grupo de } \\
\text { Pesquisa em } \\
\text { Divulgação e } \\
\text { Ensino das } \\
\text { Ciências }\end{array}$ & $\begin{array}{l}\text { Marco Aurélio } \\
\text { Alvarenga } \\
\text { Monteiro e } \\
\text { Isabel Cristina } \\
\text { de Castro } \\
\text { Kondarzewski }\end{array}$ & $\begin{array}{l}\text { Universidade } \\
\text { Estadual } \\
\text { Paulista Júlio } \\
\text { de Mesquita } \\
\text { Filho - UNESP }\end{array}$ & $\begin{array}{l}\text { http://dgp.cnpq.br/dgp/espelh } \\
\underline{\text { ogrupo/1833779755100156 }}\end{array}$ & Educação \\
\hline $\begin{array}{l}\text { Grupo de } \\
\text { Pesquisa em } \\
\text { Educação em } \\
\text { Ciências e } \\
\text { Complexidade }\end{array}$ & $\begin{array}{l}\text { Cristiano } \\
\text { Rodrigues de } \\
\text { Mattos }\end{array}$ & $\begin{array}{l}\text { Universidade } \\
\text { de São Paulo - } \\
\text { USP }\end{array}$ & $\begin{array}{l}\text { http://dgp.cnpq.br/dgp/espelh } \\
\underline{\text { ogrupo/6735481115781113 }}\end{array}$ & Educação \\
\hline $\begin{array}{l}\text { Grupo de } \\
\text { Pesquisa em } \\
\text { Teoria Sócio } \\
\text { Histórica } \\
\text { Cultural }\end{array}$ & $\begin{array}{l}\text { Deivis Perez e } \\
\text { Joao Batista } \\
\text { Martins }\end{array}$ & $\begin{array}{l}\text { Universidade } \\
\text { Estadual } \\
\text { Paulista Júlio } \\
\text { de Mesquita } \\
\text { Filho - UNESP }\end{array}$ & $\begin{array}{l}\text { http://dgp.cnpq.br/dgp/espelh } \\
\underline{\text { ogrupo/2883726566811995 }}\end{array}$ & Psicologia \\
\hline
\end{tabular}




\begin{tabular}{|c|c|c|c|c|}
\hline $\begin{array}{l}\text { Grupo de } \\
\text { Pesquisa } \\
\text { Pensamento e } \\
\text { Linguagem - } \\
\text { GPPL13 }\end{array}$ & $\begin{array}{l}\text { Ana Luiza } \\
\text { Bustamante } \\
\text { Smolka e Luci } \\
\text { Banks- Leite }\end{array}$ & $\begin{array}{l}\text { Universidade } \\
\text { Estadual de } \\
\text { Campinas - } \\
\text { UNICAMP }\end{array}$ & $\begin{array}{l}\text { http://dgp.cnpq.br/dgp/espelh } \\
\underline{\text { ogrupo/17058 }}\end{array}$ & Educação \\
\hline $\begin{array}{l}\text { Grupo de } \\
\text { Pesquisa } \\
\text { Relações de } \\
\text { Ensino e } \\
\text { Trabalho } \\
\text { Docente }\end{array}$ & $\begin{array}{l}\text { Ana Paula de } \\
\text { Freitas e } \\
\text { Daniela Dias } \\
\text { dos Anjos }\end{array}$ & $\begin{array}{l}\text { Universidade } \\
\text { São Francisco - } \\
\text { USF/Campus } \\
\text { de Itatiba - SP }\end{array}$ & $\begin{array}{l}\text { http://dgp.cnpq.br/dgp/espelh } \\
\underline{\text { ogrupo/0199785304633620 }}\end{array}$ & Educação \\
\hline $\begin{array}{l}\text { Grupo de } \\
\text { Pesquisas e } \\
\text { Estudos em } \\
\text { Geografia da } \\
\text { Infância } \\
\text { (GRUPEGI) }\end{array}$ & $\begin{array}{l}\text { Jader Janer } \\
\text { Moreira Lopes }\end{array}$ & $\begin{array}{l}\text { Universidade } \\
\text { Federal } \\
\text { Fluminense - } \\
\text { UFF }\end{array}$ & $\begin{array}{l}\text { http://dgp.cnpq.br/dgp/espelh } \\
\underline{\text { ogrupo/4804224744077920 }}\end{array}$ & Educação \\
\hline $\begin{array}{l}\text { Grupo de } \\
\text { Pesquisas e } \\
\text { Estudos } \\
\text { Marxismo, } \\
\text { Educação e } \\
\text { Cultura }\end{array}$ & $\begin{array}{l}\text { Áurea de } \\
\text { Carvalho Costa }\end{array}$ & $\begin{array}{l}\text { Universidade } \\
\text { Estadual } \\
\text { Paulista Júlio } \\
\text { de Mesquita } \\
\text { Filho - UNESP }\end{array}$ & $\begin{array}{l}\text { http://dgp.cnpq.br/dgp/espelh } \\
\underline{\text { ogrupo/2832894437120067 }}\end{array}$ & Educação \\
\hline $\begin{array}{l}\text { Implicações } \\
\text { Pedagógicas da } \\
\text { Teoria } \\
\text { Histórico- } \\
\text { Cultural }{ }^{14}\end{array}$ & $\begin{array}{l}\text { Sueli } \\
\text { Guadalupe de } \\
\text { Lima Mendonça } \\
\text { e Suely Amaral } \\
\text { Mello }\end{array}$ & $\begin{array}{l}\text { Universidade } \\
\text { Estadual } \\
\text { Paulista Júlio } \\
\text { de Mesquita } \\
\text { Filho - UNESP }\end{array}$ & $\begin{array}{l}\text { http://dgp.cnpq.br/dgp/espelh } \\
\underline{\text { ogrupo/4837738705384807 }}\end{array}$ & Educação \\
\hline $\begin{array}{l}\text { Laboratório de } \\
\text { Educação e } \\
\text { Desenvolviment } \\
\text { o Psicológico }\end{array}$ & $\begin{array}{l}\text { Maria Eliza } \\
\text { Mattosinho e } \\
\text { Maria Flávia } \\
\text { Silveira } \\
\text { Barbosa }\end{array}$ & $\begin{array}{l}\text { Universidade } \\
\text { de São Paulo - } \\
\text { USP }\end{array}$ & $\begin{array}{l}\text { dgp.cnpq.br/dgp/espelhogrup } \\
\text { o/0514496438828886 }\end{array}$ & Educação \\
\hline $\begin{array}{l}\text { Laboratório } \\
\text { Interdisciplina } \\
\text { r Ciências } \\
\text { Humanas, } \\
\text { Sociais e Saúde } \\
\text { - LICHSS }\end{array}$ & $\begin{array}{l}\text { Eunice } \\
\text { Nakamura e } \\
\text { Cristiane } \\
\text { Gonçalves da } \\
\text { Silva }\end{array}$ & $\begin{array}{l}\text { Universidade } \\
\text { Federal de São } \\
\text { Paulo - } \\
\text { UNIFESP }\end{array}$ & $\begin{array}{l}\text { http://dgp.cnpq.br/dgp/espelh } \\
\underline{\text { ogrupo/1656199191534446 }}\end{array}$ & Saúde Coletiva \\
\hline $\begin{array}{l}\text { NEPPEM- } \\
\text { Núcleo de } \\
\text { Estudos e } \\
\text { Pesquisa em } \\
\text { Psicologia } \\
\text { Social, } \\
\text { Educação e } \\
\text { Saúde: } \\
\text { contribuições } \\
\text { do marxismo }\end{array}$ & $\begin{array}{l}\text { Angelo Antonio } \\
\text { Abrantes e } \\
\text { Sueli Terezinha } \\
\text { Ferrero Martin }\end{array}$ & $\begin{array}{l}\text { Universidade } \\
\text { Estadual } \\
\text { Paulista Júlio } \\
\text { de Mesquita } \\
\text { Filho - UNESP }\end{array}$ & $\begin{array}{l}\text { http://dgp.cnpq.br/dgp/espelh } \\
\text { ogrupo/7442957725493598 }\end{array}$ & Psicologia \\
\hline $\begin{array}{l}\text { Núcleo de } \\
\text { Estudos e } \\
\text { Pesquisas } \\
\text { sobre a Escola } \\
\text { de Vigotsky - } \\
\text { NEEVY }\end{array}$ & $\begin{array}{l}\text { Maria } \\
\text { Aparecida } \\
\text { Mello e Douglas } \\
\text { Aparecido de } \\
\text { Campos }\end{array}$ & $\begin{array}{l}\text { Universidade } \\
\text { Federal de São } \\
\text { Carlos - } \\
\text { UFSCAR }\end{array}$ & $\begin{array}{l}\text { http://dgp.cnpq.br/dgp/espelh } \\
\underline{\text { ogrupo/4534653151201521 }}\end{array}$ & Educação \\
\hline
\end{tabular}

13 Este é o grupo mais antigo em funcionamento, com ano de formação em 1992 no DGP-CNPq, mas com início de funcionamento na Faculdade de Educação da UNICAMP em 1987.

14 Grupo com data de formação em 1997, constituindo-se no $2^{\circ}$ grupo mais antigo cadastrado no DGP-CNPq e em funcionamento. 


\begin{tabular}{|c|c|c|c|c|}
\hline $\begin{array}{l}\text { Núcleo de } \\
\text { Estudos em } \\
\text { Educação, } \\
\text { Trabalho e } \\
\text { Saúde - NEETS }\end{array}$ & $\begin{array}{l}\text { Luiz Gonzaga } \\
\text { Chiavegato } \\
\text { Filho }\end{array}$ & $\begin{array}{l}\text { Universidade } \\
\text { Federal de São } \\
\text { João Del Rei - } \\
\text { UFSJ }\end{array}$ & $\begin{array}{l}\text { http://dgp.cnpq.br/dgp/espelh } \\
\underline{\text { ogrupo/2252223001612200 }}\end{array}$ & Psicologia \\
\hline $\begin{array}{l}\text { Núcleo de } \\
\text { pesquisa em } \\
\text { ensino de } \\
\text { Geografia: } \\
\text { articulação } \\
\text { entre a } \\
\text { universidade e } \\
\text { a escola de } \\
\text { Educação } \\
\text { Básica }\end{array}$ & $\begin{array}{l}\text { Márcia Cristina } \\
\text { de Oliveira } \\
\text { Mello }\end{array}$ & $\begin{array}{l}\text { Universidade } \\
\text { Estadual } \\
\text { Paulista Júlio } \\
\text { de Mesquita } \\
\text { Filho - UNESP }\end{array}$ & $\begin{array}{l}\text { http://dgp.cnpq.br/dgp/espelh } \\
\text { ogrupo/41663 }\end{array}$ & Educação \\
\hline $\begin{array}{l}\text { Núcleo de } \\
\text { Tradução, } \\
\text { Estudos e } \\
\text { Interpretação } \\
\text { das obras dos } \\
\text { representantes } \\
\text { da Teoria } \\
\text { histórico- } \\
\text { cultural }\end{array}$ & $\begin{array}{l}\text { Zoia Ribeiro } \\
\text { Prestes e } \\
\text { Elizabeth } \\
\text { Tunes }\end{array}$ & $\begin{array}{l}\text { Universidade } \\
\text { Federal } \\
\text { Fluminense - } \\
\text { UFF }\end{array}$ & $\begin{array}{l}\text { http://dgp.cnpq.br/dgp/espelh } \\
\underline{\text { ogrupo/35929 }}\end{array}$ & Educação \\
\hline $\begin{array}{l}\text { Núcleo de } \\
\text { Investigações } \\
\text { Clínicas e } \\
\text { Educacionais }\end{array}$ & $\begin{array}{l}\text { Lucia Maria } \\
\text { Gonzales } \\
\text { Barbosa }\end{array}$ & $\begin{array}{l}\text { Universidade } \\
\text { Nove de Julho }\end{array}$ & $\begin{array}{l}\text { http://dgp.cnpq.br/dgp/espelh } \\
\underline{\text { ogrupo/7658049483449814 }}\end{array}$ & Psicologia \\
\hline $\begin{array}{l}\text { Pedagogia } \\
\text { histórico- } \\
\text { crítica e } \\
\text { educação } \\
\text { escolar }\end{array}$ & $\begin{array}{l}\text { Ana Carolina } \\
\text { Galvão } \\
\text { Marsiglia e } \\
\text { Maria Amélia } \\
\text { Dalvi Salgueiro }\end{array}$ & $\begin{array}{l}\text { Universidade } \\
\text { Federal do } \\
\text { Espírito Santo - } \\
\text { UFES }\end{array}$ & $\begin{array}{l}\text { http://dgp.cnpq.br/dgp/espelh } \\
\underline{\text { ogrupo/5679671098647393 }}\end{array}$ & Educação \\
\hline $\begin{array}{l}\text { Psicologia e } \\
\text { escolarização: } \\
\text { Políticas } \\
\text { públicas e } \\
\text { atividade } \\
\text { profissional na } \\
\text { perspectiva } \\
\text { histórico- } \\
\text { crítica }\end{array}$ & $\begin{array}{l}\text { Marilene } \\
\text { Proença Rebello } \\
\text { de Souza e } \\
\text { Marli Lucia } \\
\text { Tonatto Zibett }\end{array}$ & $\begin{array}{l}\text { Universidade } \\
\text { de São Paulo - } \\
\text { USP }\end{array}$ & $\begin{array}{l}\text { http://dgp.cnpq.br/dgp/espelh } \\
\text { ogrupo/3858502593355579 }\end{array}$ & Psicologia \\
\hline $\begin{array}{l}\text { Psicologia } \\
\text { Histórico- } \\
\text { Cultural e } \\
\text { Saúde Coletiva }\end{array}$ & $\begin{array}{l}\text { Sueli Terezinha } \\
\text { Ferrero Martin } \\
\text { e Maria } \\
\text { Dionísia do } \\
\text { Amaral Dias }\end{array}$ & $\begin{array}{l}\text { Universidade } \\
\text { Estadual } \\
\text { Paulista - } \\
\text { UNESP }\end{array}$ & $\begin{array}{l}\text { http://dgp.cnpq.br/dgp/espelh } \\
\underline{\text { ogrupo/82976 }}\end{array}$ & Saúde Coletiva \\
\hline $\begin{array}{l}\text { Psicologia, } \\
\text { Educação e } \\
\text { Teoria } \\
\text { Histórico- } \\
\text { cultural }\end{array}$ & $\begin{array}{l}\text { Silvia Maria } \\
\text { Cintra da } \\
\text { Silva e Anabela } \\
\text { Almeida Costa } \\
\text { e Santos } \\
\text { Peretta }\end{array}$ & $\begin{array}{l}\text { Universidade } \\
\text { Federal de } \\
\text { Uberlândia - } \\
\text { UFU }\end{array}$ & $\begin{array}{l}\text { http://dgp.cnpq.br/dgp/espelh } \\
\underline{\text { ogrupo/4599130448068854 }}\end{array}$ & Psicologia \\
\hline $\begin{array}{l}\text { PSICOLOGIA, } \\
\text { SOCIEDADE E } \\
\text { EDUCAÇÃO NA } \\
\text { AMÉRICA } \\
\text { LATINA }\end{array}$ & $\begin{array}{l}\text { Marilene } \\
\text { Proença Rebello } \\
\text { de Souza e } \\
\text { Luciane Maria } \\
\text { Schlindwein }\end{array}$ & $\begin{array}{l}\text { Universidade } \\
\text { de São Paulo - } \\
\text { USP }\end{array}$ & $\begin{array}{l}\text { http://dgp.cnpq.br/dgp/espelh } \\
\underline{\text { ogrupo/6848349615600316 }}\end{array}$ & Psicologia \\
\hline $\begin{array}{l}\text { Rumo à } \\
\text { Educação } \\
\text { Matemática }\end{array}$ & $\begin{array}{l}\text { Siobhan } \\
\text { Victoria Healy }\end{array}$ & $\begin{array}{l}\text { Universidade } \\
\text { Anhanguera de } \\
\text { São Paulo - }\end{array}$ & $\begin{array}{l}\text { http://dgp.cnpq.br/dgp/espelh } \\
\text { ogrupo/1588396630800678 }\end{array}$ & Educação \\
\hline
\end{tabular}




\begin{tabular}{|c|c|c|c|c|}
\hline Inclusiva & & UNIAN/SP & & \\
\hline $\begin{array}{l}\text { Saúde na } \\
\text { Educação } \\
\text { Básica e } \\
\text { Abordagem } \\
\text { Histórico- } \\
\text { Cultural - } \\
\text { SEBAHC }\end{array}$ & $\begin{array}{l}\text { Marlene } \\
\text { Fagundes } \\
\text { Carvalho } \\
\text { Gonçalves e } \\
\text { Luciane Sa de } \\
\text { Andrade }\end{array}$ & $\begin{array}{l}\text { Universidade } \\
\text { de São Paulo - } \\
\text { USP }\end{array}$ & $\begin{array}{l}\text { http://dgp.cnpq.br/dgp/espelh } \\
\underline{\text { ogrupo/363451 }}\end{array}$ & Enfermagem \\
\hline $\begin{array}{l}\text { Teoria da } \\
\text { Histórico- } \\
\text { cultural da } \\
\text { Atividade na } \\
\text { pesquisa em } \\
\text { Educação } \\
\text { (CHATER) }\end{array}$ & $\begin{array}{l}\text { Teresinha Fumi } \\
\text { Kawasaki e } \\
\text { André Augusto } \\
\text { Deodato }\end{array}$ & $\begin{array}{l}\text { Universidade } \\
\text { Federal de } \\
\text { Minas Gerais - } \\
\text { UFMG }\end{array}$ & $\begin{array}{l}\text { http://dgp.cnpq.br/dgp/espelh } \\
\text { ogrupo/12838 }\end{array}$ & Educação \\
\hline
\end{tabular}

\begin{tabular}{|c|c|c|c|c|}
\hline $\begin{array}{l}\text { Nome do grupo } \\
\text { de pesquisa }\end{array}$ & $\begin{array}{l}\text { Líder(es) do } \\
\text { grupo: }\end{array}$ & $\begin{array}{l}\text { Instituição de } \\
\text { origem }\end{array}$ & Espelho do grupo & $\begin{array}{c}\text { Área } \\
\text { predominante }\end{array}$ \\
\hline \multicolumn{5}{|c|}{ REGIÃO SUL } \\
\hline $\begin{array}{l}\text { As implicações } \\
\text { da pós- } \\
\text { modernidade na } \\
\text { constituição da } \\
\text { subjetividade do } \\
\text { adolescente }\end{array}$ & Marcos Maestri & $\begin{array}{l}\text { Universidade } \\
\text { Estadual de } \\
\text { Maringá - UEM }\end{array}$ & $\begin{array}{l}\underline{\text { http://dgp.cnpq.br/dgp/espelh }} \\
\underline{\text { ogrupo/6387037514881809 }}\end{array}$ & Psicologia \\
\hline $\begin{array}{l}\text { Educação a } \\
\text { distância: mitos } \\
\text { e desafios }\end{array}$ & $\begin{array}{l}\text { Christiane } \\
\text { Martinatti } \\
\text { Maia e Graciela } \\
\text { Maria Lima } \\
\text { López }\end{array}$ & $\begin{array}{l}\text { Universidade } \\
\text { Luterana do } \\
\text { Brasil - } \\
\text { ULBRA } \\
\text { (Farroupilha- } \\
\text { RS) }\end{array}$ & $\begin{array}{l}\text { http://dgp.cnpq.br/espelhogru } \\
\text { po/3998199370552350 } \\
\text { Obs.: Link do grupo no DGP } \\
\text { não dá mais acesso ao grupo }\end{array}$ & Educação \\
\hline $\begin{array}{l}\text { Educação e } \\
\text { psicologia } \\
\text { Histórico- } \\
\text { cultural }\end{array}$ & $\begin{array}{l}\text { Magda Floriana } \\
\text { Damiani }\end{array}$ & $\begin{array}{l}\text { Universidade } \\
\text { Federal de } \\
\text { Pelotas }\end{array}$ & $\begin{array}{l}\text { http://dgp.cnpq.br/dgp/espelh } \\
\text { ogrupo/7897199321773506 }\end{array}$ & Educação \\
\hline $\begin{array}{l}\text { Educação } \\
\text { Matemática: } \\
\text { uma } \\
\text { abordagem } \\
\text { histórico- } \\
\text { cultural }\end{array}$ & $\begin{array}{l}\text { Ademir } \\
\text { Damazio e } \\
\text { Josélia Euzébio } \\
\text { da Rosa }\end{array}$ & $\begin{array}{l}\text { Universidade } \\
\text { do Extremo Sul } \\
\text { Catarinense - } \\
\text { UNESC }\end{array}$ & $\begin{array}{l}\text { http://dgp.cnpq.br/dgp/espelh } \\
\text { ogrupo/9631926533632617 }\end{array}$ & Educação \\
\hline $\begin{array}{l}\text { Ensino, } \\
\text { Aprendizagem } \\
\text { e Conteúdo } \\
\text { Escolar }\end{array}$ & $\begin{array}{l}\text { Maria } \\
\text { Terezinha } \\
\text { Bellanda } \\
\text { Galuch e } \\
\text { Glaciane } \\
\text { Cristina Xavier } \\
\text { Mashiba }\end{array}$ & $\begin{array}{l}\text { Universidade } \\
\text { Estadual de } \\
\text { Maringá - UEM }\end{array}$ & $\begin{array}{l}\text { http://dgp.cnpq.br/dgp/espelh } \\
\text { ogrupo/7174477310111499 }\end{array}$ & Educação \\
\hline $\begin{array}{l}\text { Estudo das } \\
\text { teorias e } \\
\text { práticas } \\
\text { pedagógicas na } \\
\text { perspectiva } \\
\text { crítica da } \\
\text { educação } \\
\text { escolar }\end{array}$ & $\begin{array}{l}\text { Fátima } \\
\text { Aparecida de } \\
\text { Souza Francioli } \\
\text { e Nilva de } \\
\text { Oliveira Brito } \\
\text { dos Santos }\end{array}$ & $\begin{array}{l}\text { Universidade } \\
\text { Estadual do } \\
\text { Paraná - } \\
\text { UNESPAR }\end{array}$ & $\begin{array}{l}\text { http://dgp.cnpq.br/dgp/espelh } \\
\text { ogrupo/8364702775850552 }\end{array}$ & Educação \\
\hline
\end{tabular}




\begin{tabular}{|c|c|c|c|c|}
\hline $\begin{array}{l}\text { Estudos Sócio } \\
\text { culturais no } \\
\text { Ensino de } \\
\text { Ciências }\end{array}$ & $\begin{array}{l}\text { Alvaro } \\
\text { Leonardi Ayala } \\
\text { Filho }\end{array}$ & $\begin{array}{l}\text { Universidade } \\
\text { Federal de } \\
\text { Pelotas - } \\
\text { UFPEL }\end{array}$ & $\begin{array}{l}\text { http://dgp.cnpq.br/dgp/espelh } \\
\text { ogrupo/2312920629135739 }\end{array}$ & Física \\
\hline $\begin{array}{l}\text { GEPEPPE- } \\
\text { Grupo de } \\
\text { Pesquisa e } \\
\text { Ensino em } \\
\text { Políticas } \\
\text { Públicas em } \\
\text { Educação e } \\
\text { Processos de } \\
\text { Escolarização }\end{array}$ & $\begin{array}{l}\text { Maria Cristina } \\
\text { Cavaleiro e } \\
\text { Thaís de Sá } \\
\text { Gomes Novaes }\end{array}$ & $\begin{array}{l}\text { Universidade } \\
\text { Estadual do } \\
\text { Norte do } \\
\text { Paraná - UENP }\end{array}$ & $\begin{array}{l}\text { http://dgp.cnpq.br/dgp/espelh } \\
\text { ogrupo/8162430117788075 }\end{array}$ & Educação \\
\hline $\begin{array}{l}\text { Grupo de } \\
\text { Estudos e } \\
\text { Pesquisa em } \\
\text { Educação } \\
\text { Especial - } \\
\text { GEPEE }\end{array}$ & $\begin{array}{l}\text { Elisabeth } \\
\text { Rossetto e } \\
\text { Rejane Teixeira } \\
\text { Coelho }\end{array}$ & $\begin{array}{l}\text { Universidade } \\
\text { Estadual do } \\
\text { Oeste do } \\
\text { Paraná - UENP }\end{array}$ & $\begin{array}{l}\text { http://dgp.cnpq.br/dgp/espelh } \\
\text { ogrupo/6606215123951447 }\end{array}$ & Educação \\
\hline $\begin{array}{l}\text { Grupo de } \\
\text { Estudos e } \\
\text { Pesquisa em } \\
\text { Ontologia } \\
\text { Crítica } \\
\text { (GEPOC) }\end{array}$ & $\begin{array}{l}\text { Patrícia Laura } \\
\text { Torriglia e } \\
\text { Vidalcir } \\
\text { Ortigara }\end{array}$ & $\begin{array}{l}\text { Universidade } \\
\text { Federal de } \\
\text { Santa Catarina } \\
\text { - UFSC }\end{array}$ & $\begin{array}{l}\text { http://dgp.cnpq.br/espelhogru } \\
\text { po/4532643323109726 } \\
\text { Obs.: Link do grupo no DGP } \\
\text { não dá mais acesso ao grupo }\end{array}$ & Educação \\
\hline $\begin{array}{l}\text { Grupo de } \\
\text { Estudos e } \\
\text { Pesquisas em } \\
\text { Educação } \\
\text { Matemática - } \\
\text { GEPEMat }\end{array}$ & $\begin{array}{l}\text { Anemari } \\
\text { Roesler } \\
\text { Luersen Vieira } \\
\text { Lopes e Liane } \\
\text { Teresinha } \\
\text { Wendling Roos }\end{array}$ & $\begin{array}{l}\text { Universidade } \\
\text { Federal de } \\
\text { Santa Maria - } \\
\text { UFMS }\end{array}$ & $\begin{array}{l}\text { http://dgp.cnpq.br/dgp/espelh } \\
\text { ogrupo/5380846243852482 }\end{array}$ & Educação \\
\hline $\begin{array}{l}\text { Grupo de } \\
\text { Estudos e } \\
\text { Pesquisas em } \\
\text { Educação, } \\
\text { Preconceito e } \\
\text { Formação de } \\
\text { Professores }\end{array}$ & $\begin{array}{l}\text { Renata de } \\
\text { Almeida Vieira }\end{array}$ & $\begin{array}{l}\text { Universidade } \\
\text { Estadual de } \\
\text { Maringá - UEM }\end{array}$ & $\begin{array}{l}\text { http://dgp.cnpq.br/espelhogru } \\
\text { po/9798123995351375. Obs.: } \\
\text { Link do grupo no DGP não dá } \\
\text { mais acesso ao grupo }\end{array}$ & Educação \\
\hline $\begin{array}{l}\text { Grupo de } \\
\text { Estudos e } \\
\text { Pesquisas em } \\
\text { Educação, } \\
\text { Saúde e } \\
\text { Psicologia } \\
\text { Histórico } \\
\text { Cultural - } \\
\text { GEPESPHC }\end{array}$ & $\begin{array}{l}\text { Rejane Teixeira } \\
\text { Coelho }\end{array}$ & $\begin{array}{l}\text { Universidade } \\
\text { Estadual do } \\
\text { Oeste do } \\
\text { Paraná - } \\
\text { UNIOESTE }\end{array}$ & $\begin{array}{l}\text { http://dgp.cnpq.br/dgp/espelh } \\
\text { ogrupo/8210622853452648 }\end{array}$ & Educação \\
\hline $\begin{array}{l}\text { Grupo de } \\
\text { Estudos em } \\
\text { Psicologia } \\
\text { Concreta }\end{array}$ & $\begin{array}{l}\text { Marcelo Ubiali } \\
\text { Ferracioli e } \\
\text { Giselle Modé } \\
\text { Magalhães }\end{array}$ & $\begin{array}{l}\text { Universidade } \\
\text { Estadual de } \\
\text { Ponta Grossa - } \\
\text { UFPG }\end{array}$ & $\begin{array}{l}\text { http://dgp.cnpq.br/dgp/espelh } \\
\text { ogrupo/8401972394918517 }\end{array}$ & Psicologia \\
\hline $\begin{array}{l}\text { Grupo de } \\
\text { Pesquisa e } \\
\text { Estudos em } \\
\text { Educação } \\
\text { Infantil }\end{array}$ & $\begin{array}{l}\text { Marta Chaves e } \\
\text { Gizeli } \\
\text { Aparecida } \\
\text { Ribeiro de } \\
\text { Alencar }\end{array}$ & $\begin{array}{l}\text { Universidade } \\
\text { Estadual de } \\
\text { Maringá - UEM }\end{array}$ & $\frac{\text { http://dgp.cnpq.br/dgp/espelh }}{\text { ogrupo/8433138424054924 }}$ & Educação \\
\hline $\begin{array}{l}\text { Laboratório de } \\
\text { Estudos em } \\
\text { Psicologia } \\
\text { Sociohistórica - } \\
\text { LAEPSO }\end{array}$ & $\begin{array}{l}\text { Alvaro Marcel } \\
\text { Palomo Alves e } \\
\text { Ednéia José } \\
\text { Martins } \\
\text { Zaniani }\end{array}$ & $\begin{array}{l}\text { Universidade } \\
\text { Estadual de } \\
\text { Maringá - UEM }\end{array}$ & $\begin{array}{l}\text { http://dgp.cnpq.br/dgp/espelh } \\
\text { ogrupo/1637093860965171 }\end{array}$ & Psicologia \\
\hline
\end{tabular}




\begin{tabular}{|c|c|c|c|c|}
\hline $\begin{array}{l}\text { Laboratório de } \\
\text { Mudança: } \\
\text { Pesquisa em } \\
\text { Educação e } \\
\text { Saúde }\end{array}$ & $\begin{array}{l}\text { Marcelo } \\
\text { Fernandes } \\
\text { Capilheira e } \\
\text { Daniela Fuhro } \\
\text { Vilas Boas }\end{array}$ & $\begin{array}{l}\text { Universidade } \\
\text { Federal de } \\
\text { Pelotas - } \\
\text { UFPEL }\end{array}$ & $\begin{array}{l}\text { http://dgp.cnpq.br/dgp/espelh } \\
\underline{\text { ogrupo/1185366913514261 }}\end{array}$ & Educação \\
\hline $\begin{array}{l}\text { Núcleo de } \\
\text { Estudos } \\
\text { Trabalho e } \\
\text { Constituição do } \\
\text { Sujeito - } \\
\text { NETCOS }\end{array}$ & $\begin{array}{l}\text { Maria Chalfin } \\
\text { Coutinho e } \\
\text { Geruza Tavares } \\
\text { D'Avil }\end{array}$ & $\begin{array}{l}\text { Universidade } \\
\text { Federal de } \\
\text { Santa Catarina } \\
\text { - UFSC }\end{array}$ & $\begin{array}{l}\text { http://dgp.cnpq.br/dgp/espelh } \\
\underline{\text { ogrupo/0644063140501088 }}\end{array}$ & Psicologia \\
\hline $\begin{array}{l}\text { Organizações e } \\
\text { subjetividade }\end{array}$ & $\begin{array}{l}\text { Fabio Vizeu } \\
\text { Ferreira e } \\
\text { Eduardo André } \\
\text { Teixeira Ayrosa }\end{array}$ & $\begin{array}{l}\text { Universidade } \\
\text { Positivo - } \\
\text { POSITIVO }\end{array}$ & $\begin{array}{l}\text { http://dgp.cnpq.br/dgp/espelh } \\
\underline{\text { ogrupo/5816029121076143 }}\end{array}$ & Administração \\
\hline $\begin{array}{l}\text { Psicologia e } \\
\text { Processos } \\
\text { Educacio-nais }\end{array}$ & $\begin{array}{l}\text { Neiva de } \\
\text { Assis e } \\
\text { Apoliana } \\
\text { Regina Groff }\end{array}$ & $\begin{array}{l}\text { Universidade } \\
\text { Federal de } \\
\text { Santa Catarina } \\
\text { - UFSC }\end{array}$ & $\begin{array}{l}\text { http://dgp.cnpq.br/dgp/espelh } \\
\text { ogrupo/9976205865845934 }\end{array}$ & Psicologia \\
\hline $\begin{array}{l}\text { Psicologia e } \\
\text { Educação na } \\
\text { perspectiva } \\
\text { Histórico- } \\
\text { Cultural }\end{array}$ & $\begin{array}{l}\text { Alayde Maria } \\
\text { Pinto } \\
\text { Digiovanni }\end{array}$ & $\begin{array}{l}\text { Universidade } \\
\text { Estadual do } \\
\text { Centro-Oeste - } \\
\text { UNICENTRO }\end{array}$ & $\frac{\text { http://dgp.cnpq.br/dgp/espelh }}{\underline{\text { ogrupo/0774725092260603 }}}$ & Psicologia \\
\hline $\begin{array}{l}\text { Psicologia } \\
\text { histórico- } \\
\text { cultural e } \\
\text { educação }\end{array}$ & $\begin{array}{l}\text { Marilda } \\
\text { Gonçalves Dias } \\
\text { Facci e Silvana } \\
\text { Calvo Tuleski }\end{array}$ & $\begin{array}{l}\text { Universidade } \\
\text { Estadual de } \\
\text { Maringá - UEM }\end{array}$ & $\begin{array}{l}\text { http://dgp.cnpq.br/dgp/espelh } \\
\text { ogrupo/0996458976637832 }\end{array}$ & Psicologia \\
\hline $\begin{array}{l}\text { Tecnologia e } \\
\text { Aprendizagem } \\
\text { de Língua }\end{array}$ & $\begin{array}{l}\text { Vilson Jose } \\
\text { Leffa }\end{array}$ & $\begin{array}{l}\text { Universidade } \\
\text { Católica de } \\
\text { Pelotas - } \\
\text { UCPEL }\end{array}$ & $\begin{array}{l}\text { http://dgp.cnpq.br/dgp/espelh } \\
\underline{\text { ogrupo/5814457895784506 }}\end{array}$ & Linguística \\
\hline $\begin{array}{l}\text { Teoria } \\
\text { Histórico- } \\
\text { cultural e } \\
\text { Educação } \\
\text { Matemática }\end{array}$ & $\begin{array}{l}\text { Neiva Ignês } \\
\text { Grando }\end{array}$ & $\begin{array}{l}\text { Universidade } \\
\text { de Passo Fundo } \\
\text { - UPF }\end{array}$ & $\begin{array}{l}\text { http://dgp.cnpq.br/dgp/espelh } \\
\text { ogrupo/5694615356405164 }\end{array}$ & Educação \\
\hline
\end{tabular}

\begin{tabular}{|c|c|c|c|c|}
\hline $\begin{array}{l}\text { Nome do grupo } \\
\text { de pesquisa }\end{array}$ & $\begin{array}{l}\text { Líder(es) do } \\
\text { grupo }\end{array}$ & $\begin{array}{c}\text { Instituição de } \\
\text { origem }\end{array}$ & Espelho do grupo & $\begin{array}{c}\text { Área } \\
\text { predominante }\end{array}$ \\
\hline \multicolumn{5}{|c|}{ REGIÃO NORDESTE } \\
\hline $\begin{array}{l}\text { Currículo, EJA } \\
\text { e Diversidade } \\
\text { Cultural }\end{array}$ & $\begin{array}{l}\text { Jose Fernando } \\
\text { Manzke e } \\
\text { Elisangela } \\
\text { Santos de } \\
\text { Amorim }\end{array}$ & $\begin{array}{l}\text { Universidade } \\
\text { Federal do } \\
\text { Maranhão - } \\
\text { UFMA }\end{array}$ & $\begin{array}{l}\underline{\text { http://dgp.cnpq.br/dgp/espelh }} \\
\underline{\text { ogrupo/8302388943831136 }}\end{array}$ & Educação \\
\hline $\begin{array}{l}\text { Educação e } \\
\text { Infância }\end{array}$ & $\begin{array}{l}\text { Maria da Penha } \\
\text { Teófilo e José } \\
\text { Carlos Melo }\end{array}$ & $\begin{array}{l}\text { Universidade } \\
\text { Federal do } \\
\text { Maranhão - } \\
\text { UFMA }\end{array}$ & $\begin{array}{l}\text { http://dgp.cnpq.br/espelhogru } \\
\text { po/4756682883779787 } \\
\text { Obs.: Link do grupo no DGP } \\
\text { não dá mais acesso ao grupo }\end{array}$ & Educação \\
\hline $\begin{array}{l}\text { Educação } \\
\text { Especial }\end{array}$ & $\begin{array}{l}\text { Geandra } \\
\text { Cláudia Silva } \\
\text { Santos }\end{array}$ & $\begin{array}{l}\text { Universidade } \\
\text { Estadual do } \\
\text { Ceará - UECE }\end{array}$ & $\begin{array}{l}\text { http://dgp.cnpq.br/dgp/espelh } \\
\underline{\text { ogrupo/2625909927799684 }}\end{array}$ & Educação \\
\hline $\begin{array}{l}\text { FORMAR - } \\
\text { Formação de } \\
\text { professores na } \\
\text { Perspectiva } \\
\text { Histórico- }\end{array}$ & $\begin{array}{l}\text { Hilda Maria } \\
\text { Martins } \\
\text { Bandeira } \\
\text { Wellington de }\end{array}$ & $\begin{array}{l}\text { Universidade } \\
\text { Federal do } \\
\text { Piauí - UFPI }\end{array}$ & $\begin{array}{l}\text { http://dgp.cnpq.br/dgp/espelh } \\
\underline{\text { ogrupo/8827123357383376 }}\end{array}$ & Educação \\
\hline
\end{tabular}




\begin{tabular}{|c|c|c|c|c|}
\hline Cultural & Oliveira & & & \\
\hline $\begin{array}{l}\text { Grupo De } \\
\text { Estudos Em } \\
\text { Práticas } \\
\text { Educativas E } \\
\text { Formação De } \\
\text { Professores - } \\
\text { Gepefp'p }\end{array}$ & $\begin{array}{l}\text { Francisco de } \\
\text { Assis Carvalho } \\
\text { de Almada e } \\
\text { Ilma Maria de } \\
\text { Oliveira Silva }\end{array}$ & $\begin{array}{l}\text { Universidade } \\
\text { Estadual da } \\
\text { Região } \\
\text { Tocantina do } \\
\text { MA - } \\
\text { UEMASUL }\end{array}$ & $\begin{array}{l}\text { dgp.cnpq.br/dgp/espelhogrup } \\
\underline{\text { o/0564981038626192 }}\end{array}$ & Psicologia \\
\hline $\begin{array}{l}\text { Grupo de } \\
\text { Estudos e } \\
\text { Pesquisas em } \\
\text { Educação } \\
\text { Infantil, } \\
\text { Atividade e } \\
\text { Múltiplas } \\
\text { Linguagens }\end{array}$ & $\begin{array}{l}\text { Fabricia } \\
\text { Pereira Teles }\end{array}$ & $\begin{array}{l}\text { Universidade } \\
\text { Estadual do } \\
\text { Piauí }\end{array}$ & $\begin{array}{l}\text { http://dgp.cnpq.br/dgp/espelh } \\
\text { ogrupo/9783143041705257 }\end{array}$ & Educação \\
\hline $\begin{array}{l}\text { Grupo de } \\
\text { Estudos e } \\
\text { Pesquisas } \\
\text { Histórico- } \\
\text { Culturais em } \\
\text { Formação de } \\
\text { Professores e } \\
\text { Prática } \\
\text { Pedagógica - } \\
\text { GEHFO }\end{array}$ & $\begin{array}{l}\text { Valdirene } \\
\text { gomes de Sousa } \\
\text { e Lindenora de } \\
\text { Araujo Cunha } \\
\text { Morais }\end{array}$ & $\begin{array}{l}\text { Universidade } \\
\text { Estadual do } \\
\text { Piauí - UESPI }\end{array}$ & $\begin{array}{l}\text { http://dgp.cnpq.br/dgp/espelh } \\
\underline{\text { ogrupo/8141760472919478 }}\end{array}$ & Educação \\
\hline $\begin{array}{l}\text { Grupo de } \\
\text { Estudos e } \\
\text { Pesquisas } \\
\text { sobre Ensino e } \\
\text { Modelagem } \\
\text { Matemática - } \\
\text { GEPEMM }\end{array}$ & $\begin{array}{l}\text { Ronaldo } \\
\text { Campelo da } \\
\text { Costa e Roberto } \\
\text { Arruda Lima } \\
\text { Soares }\end{array}$ & $\begin{array}{l}\text { Universidade } \\
\text { Federal do } \\
\text { Piaui }\end{array}$ & $\begin{array}{l}\text { http://dgp.cnpq.br/dgp/espelh } \\
\text { ogrupo/1570490376482462 }\end{array}$ & Matemática \\
\hline $\begin{array}{l}\text { LACELI - } \\
\text { Linguagem, } \\
\text { Ação, Crítica e } \\
\text { Educação em } \\
\text { Línguas }\end{array}$ & $\begin{array}{l}\text { Julia Maria } \\
\text { Raposo } \\
\text { Gonçalves de } \\
\text { Melo Larré }\end{array}$ & $\begin{array}{l}\text { Universidade } \\
\text { Federal Rural } \\
\text { de Pernambuco } \\
\text { UFRPE }\end{array}$ & $\begin{array}{l}\text { http://dgp.cnpq.br/dgp/espelh } \\
\text { ogrupo/6151565712966419 }\end{array}$ & Linguística \\
\hline $\begin{array}{l}\text { LAPEN - } \\
\text { Laboratório de } \\
\text { Pesquisa e } \\
\text { Extensão em } \\
\text { Neuropsicologi } \\
\text { a }\end{array}$ & $\begin{array}{l}\text { Izabel Augusta } \\
\text { Hazin Pires e } \\
\text { Cíntia Alves } \\
\text { Salgado Azoni }\end{array}$ & $\begin{array}{l}\text { Universidade } \\
\text { Federal do Rio } \\
\text { Grande do } \\
\text { Norte - UFRN }\end{array}$ & $\begin{array}{l}\text { http://dgp.cnpq.br/dgp/espelh } \\
\text { ogrupo/7203026249694095 }\end{array}$ & Psicologia \\
\hline $\begin{array}{l}\text { LEPEL-UFS } \\
\text { Grupo de } \\
\text { Estudos e } \\
\text { Pesquisa sobre } \\
\text { Teoria } \\
\text { Marxista e } \\
\text { Pedagogia } \\
\text { Socialista }\end{array}$ & $\begin{array}{l}\text { Benedito Carlos } \\
\text { Libório Caires } \\
\text { Araújo e } \\
\text { Jênisson Alves } \\
\text { de Andrade }\end{array}$ & $\begin{array}{l}\text { Universidade } \\
\text { Federal de } \\
\text { Sergipe - UFS }\end{array}$ & $\begin{array}{l}\underline{\text { http://dgp.cnpq.br/dgp/espelh }} \\
\underline{\text { ogrupo/7876439251716738 }}\end{array}$ & Educação \\
\hline $\begin{array}{l}\text { LIGUE } \\
\text { Linguagem, } \\
\text { Línguas, Escola } \\
\text { e Ensino }\end{array}$ & $\begin{array}{l}\text { Maria Cristina } \\
\text { Caldas de } \\
\text { Camargo Lima } \\
\text { Damianovic }\end{array}$ & $\begin{array}{l}\text { Universidade } \\
\text { Federal de } \\
\text { Pernambuco - } \\
\text { UFPE }\end{array}$ & $\begin{array}{l}\text { http://dgp.cnpq.br/dgp/espelh } \\
\underline{\text { ogrupo/2140399509830593 }}\end{array}$ & Letras \\
\hline
\end{tabular}

\footnotetext{
${ }^{15} \mathrm{Na}$ época do levantamento o grupo chamava-se "Educação, Infância e desenvolvimento humano na perspectiva da teoria histórico-cultural (GEIPHC) e tinha os mesmos líderes atuais.
} 


\begin{tabular}{|c|c|c|c|c|}
\hline $\begin{array}{l}\text { NEIDH - } \\
\text { Núcleo de } \\
\text { Estudos } \\
\text { Psicossociais } \\
\text { da } \\
\text { Exclusão/Inclus } \\
\text { ão e Direitos } \\
\text { Humanos }\end{array}$ & $\begin{array}{l}\text { Maria de } \\
\text { Fátima } \\
\text { Fernandes } \\
\text { Martins Catão }\end{array}$ & $\begin{array}{l}\text { Universidade } \\
\text { Federal da } \\
\text { Paraíba UFPB }\end{array}$ & $\begin{array}{l}\text { http://dgp.cnpq.br/dgp/espelh } \\
\underline{\text { ogrupo/6202954563427676 }}\end{array}$ & Psicologia \\
\hline $\begin{array}{l}\text { Núcleo de } \\
\text { Estudos e } \\
\text { Pesquisas } \\
\text { Histórico- } \\
\text { Críticas em } \\
\text { Educação e } \\
\text { Formação } \\
\text { Humana }\end{array}$ & $\begin{array}{l}\text { Maria Vilani } \\
\text { Cosme de } \\
\text { Carvalho } \\
\text { e Eliana de } \\
\text { Sousa Alencar } \\
\text { Marques }\end{array}$ & $\begin{array}{l}\text { Universidade } \\
\text { Federal do } \\
\text { Piauí - UFPI }\end{array}$ & $\begin{array}{l}\text { http://dgp.cnpq.br/dgp/espelh } \\
\text { ogrupo/1534037939920917 }\end{array}$ & Educação \\
\hline $\begin{array}{l}\text { Núcleo de } \\
\text { Estudos e } \\
\text { Pesquisas em } \\
\text { Psicologia } \\
\text { Educacional e } \\
\text { Formação } \\
\text { Docente }\end{array}$ & $\begin{array}{l}\text { Maria da Guia } \\
\text { Rodrigues } \\
\text { Rasia }\end{array}$ & $\begin{array}{l}\text { Universidade } \\
\text { Estadual da } \\
\text { Paraíba - } \\
\text { UEPB }\end{array}$ & $\begin{array}{l}\text { http://dgp.cnpq.br/dgp/espelh } \\
\text { ogrupo/7692030029220596 }\end{array}$ & Psicologia \\
\hline $\begin{array}{l}\text { Núcleo de } \\
\text { Estudos em } \\
\text { Psicologia } \\
\text { Histórico- } \\
\text { Cultural }\end{array}$ & $\begin{array}{l}\text { Herculano } \\
\text { Ricardo } \\
\text { Campos e } \\
\text { Adriane Cenci }\end{array}$ & $\begin{array}{l}\text { Universidade } \\
\text { Federal do Rio } \\
\text { Grande do } \\
\text { Norte }\end{array}$ & $\begin{array}{l}\text { http://dgp.cnpq.br/dgp/espelh } \\
\text { ogrupo/6829945233381214 }\end{array}$ & Psicologia \\
\hline $\begin{array}{l}\text { Núcleo de } \\
\text { Estudos sobre } \\
\text { Desenvolvimen } \\
\text { to e Contextos } \\
\text { Culturais }\end{array}$ & $\begin{array}{l}\text { Maria Virgínia } \\
\text { Machado } \\
\text { Dazzani e Ana } \\
\text { Cecília de } \\
\text { Sousa } \\
\text { Bittencour } \\
\text { Bastos }\end{array}$ & $\begin{array}{l}\text { Universidade } \\
\text { Federal da } \\
\text { Bahia - UFBA }\end{array}$ & $\begin{array}{l}\text { http://dgp.cnpq.br/dgp/espelh } \\
\text { ogrupo/3653441833357959 }\end{array}$ & Psicologia \\
\hline $\begin{array}{l}\text { Psicologia } \\
\text { Histórico- } \\
\text { Cultural e } \\
\text { saúde mental }\end{array}$ & $\begin{array}{l}\text { Ana Ignêz } \\
\text { Belém Lima } \\
\text { Nunes }\end{array}$ & $\begin{array}{l}\text { Universidade } \\
\text { Estadual do } \\
\text { Ceará - UECE }\end{array}$ & $\begin{array}{l}\text { http://dgp.cnpq.br/dgp/espelh } \\
\underline{\text { ogrupo/4513680404289170 }}\end{array}$ & Psicologia \\
\hline $\begin{array}{l}\text { Violência e } \\
\text { Instituições } \\
\text { Sociais }\end{array}$ & $\begin{array}{l}\text { Marilena } \\
\text { Ristum }\end{array}$ & $\begin{array}{l}\text { Universidade } \\
\text { Federal da } \\
\text { Bahia - UFBA }\end{array}$ & $\begin{array}{l}\text { http://dgp.cnpq.br/dgp/espelh } \\
\text { ogrupo/2258433606323607 }\end{array}$ & Psicologia \\
\hline
\end{tabular}

\begin{tabular}{|c|c|c|c|c|}
\hline $\begin{array}{l}\text { Nome do grupo } \\
\text { de pesquisa }\end{array}$ & $\begin{array}{l}\text { Lider(es) do } \\
\text { grupo: }\end{array}$ & $\begin{array}{c}\text { Instituição de } \\
\text { origem }\end{array}$ & Espelho do grupo & $\begin{array}{c}\text { Área } \\
\text { predominante }\end{array}$ \\
\hline \multicolumn{5}{|c|}{ Região Centro-Oeste } \\
\hline $\begin{array}{l}\text { A Teoria } \\
\text { Histórico- } \\
\text { Cultural para o } \\
\text { Ensino e } \\
\text { Aprendizagem }\end{array}$ & $\begin{array}{l}\text { Armando } \\
\text { Marino Filho e } \\
\text { Regina } \\
\text { Aparecida } \\
\text { Marques de } \\
\text { Souza }\end{array}$ & $\begin{array}{l}\text { Universidade } \\
\text { Federal de } \\
\text { Mato Grosso do } \\
\text { Sul - UFMS }\end{array}$ & $\begin{array}{l}\text { http://dgp.cnpq.br/dgp/espelh } \\
\text { ogrupo/38036 }\end{array}$ & Educação \\
\hline $\begin{array}{l}\text { Abordagem } \\
\text { Histórico- } \\
\text { Cultural em } \\
\text { Vygotsky e as } \\
\text { Contribuições }\end{array}$ & $\begin{array}{l}\text { Hidelberto de } \\
\text { Sousa Ribeiro e } \\
\text { Marilene } \\
\underline{\text { Marzari }}\end{array}$ & $\begin{array}{l}\text { Universidade } \\
\text { Federal de } \\
\text { Mato Grosso - } \\
\text { UFMT }\end{array}$ & $\begin{array}{l}\text { http://dgp.cnpq.br/dgp/espelh } \\
\text { ogrupo/4223869972631424 }\end{array}$ & Educação \\
\hline
\end{tabular}




\begin{tabular}{|c|c|c|c|c|}
\hline $\begin{array}{l}\text { para a } \\
\text { Educação }\end{array}$ & & & & \\
\hline $\begin{array}{l}\text { ALLEM- } \\
\text { Alfabetização, } \\
\text { Letramento e } \\
\text { Letramento } \\
\text { Matemático }\end{array}$ & $\begin{array}{l}\text { Ana Lúcia } \\
\text { Spindola e } \\
\text { Neusa Maria } \\
\text { Marques de } \\
\text { Souza }\end{array}$ & $\begin{array}{l}\text { Universidade } \\
\text { Federal de } \\
\text { Mato Grosso do } \\
\text { Sul - UFMS }\end{array}$ & $\begin{array}{l}\text { http://dgp.cnpq.br/dgp/espelh } \\
\text { ogrupo/2946118332223732 }\end{array}$ & Educação \\
\hline $\begin{array}{l}\text { Aspectos } \\
\text { Psicológicos do } \\
\text { Enfoque } \\
\text { Teórico Socio- } \\
\text { histórico/ } \\
\text { GEPAPET- } \\
\text { Sóciohistórico }\end{array}$ & $\begin{array}{l}\text { Inara Barbosa } \\
\text { Leão }\end{array}$ & $\begin{array}{l}\text { Universidade } \\
\text { Federal do } \\
\text { Mato Grosso do } \\
\text { Sul - UFMS }\end{array}$ & $\begin{array}{l}\text { http://dgp.cnpq.br/dgp/espelh } \\
\text { ogrupo/4539942767282976 }\end{array}$ & Psicologia \\
\hline $\begin{array}{l}\text { Colligat - (Re) } \\
\text { Pensando a } \\
\text { Formação de } \\
\text { Professores de } \\
\text { Ciências da } \\
\text { Natureza }\end{array}$ & $\begin{array}{l}\text { Simone Sendin } \\
\text { Moreira } \\
\text { Guimarães e } \\
\text { Rone de Deus } \\
\text { Paranhos }\end{array}$ & $\begin{array}{l}\text { Universidade } \\
\text { Federal de } \\
\text { Goiás - UFG }\end{array}$ & $\begin{array}{l}\text { http://dgp.cnpq.br/dgp/espelh } \\
\text { ogrupo/1387600351963813 }\end{array}$ & Educação \\
\hline $\begin{array}{l}\text { Gênero, } \\
\text { Violência e } \\
\text { Psicologia } \\
\text { Sócio- } \\
\text { histórica }^{16}\end{array}$ & $\begin{array}{l}\text { Tatiana } \\
\text { Machiavelli } \\
\text { Carmo Souza }\end{array}$ & $\begin{array}{l}\text { Universidade } \\
\text { Federal de } \\
\text { Goiás - UFG }\end{array}$ & $\begin{array}{l}\text { http://dgp.cnpq.br/dgp/espelh } \\
\text { ogrupo/77376 }\end{array}$ & Psicologia \\
\hline $\begin{array}{l}\text { GEPLEI/THC - } \\
\text { Grupo de } \\
\text { Estudos e } \\
\text { Pesquisas em } \\
\text { Linguagem, } \\
\text { Educação e } \\
\text { Infância-Teoria } \\
\text { Histórico- } \\
\text { Cultural }\end{array}$ & $\begin{array}{l}\text { Regina } \\
\text { Aparecida } \\
\text { Marques de } \\
\text { Souza e } \\
\text { Terezinha Bazé } \\
\text { de Lima }\end{array}$ & $\begin{array}{l}\text { Universidade } \\
\text { Federal do } \\
\text { Mato Grosso do } \\
\text { Sul - UFMS }\end{array}$ & $\begin{array}{l}\text { http://dgp.cnpq.br/dgp/espelh } \\
\text { ogrupo/6282851140142464 }\end{array}$ & Educação \\
\hline $\begin{array}{l}\text { Grupo de } \\
\text { Ensino- } \\
\text { Pesquisa- } \\
\text { Extensão em } \\
\text { Educação } \\
\text { Popular e } \\
\text { Estudos } \\
\text { Filosóficos e } \\
\text { Histórico- } \\
\text { Culturais } \\
\text { (GENPEX) }\end{array}$ & $\begin{array}{l}\text { Maria Clarisse } \\
\text { Vieira } \\
\text { Renato Hilário } \\
\text { dos Reis }\end{array}$ & $\begin{array}{l}\text { Universidade } \\
\text { de Brasília - } \\
\text { UNB }\end{array}$ & $\begin{array}{l}\text { http://dgp.cnpq.br/dgp/espelh } \\
\text { ogrupo/16084 }\end{array}$ & Educação \\
\hline $\begin{array}{l}\text { Grupo de } \\
\text { Estudos e } \\
\text { Pesquisa em } \\
\text { Psicologia e } \\
\text { Educação - } \\
\text { GEPPE }\end{array}$ & $\begin{array}{l}\text { Sônia da Cunha } \\
\text { Urt e Celia } \\
\text { Beatriz Piatti }\end{array}$ & $\begin{array}{l}\text { Universidade } \\
\text { Federal de } \\
\text { Mato Grosso do } \\
\text { Sul - UFMS }\end{array}$ & $\begin{array}{l}\text { http://dgp.cnpq.br/dgp/espelh } \\
\text { ogrupo/5540226844870120 }\end{array}$ & Educação \\
\hline Grupo de & Luciane Pinho & Universidade & http://dgp.cnpq.br/dgp/espelh & Psicologia \\
\hline
\end{tabular}

${ }^{16}$ Agora está nomeado como Teoria histórico-cultural e processos psicossociais e tem Janaina Cassiano Silva também como líder (acesso em 29/05/2021). 


\begin{tabular}{|c|c|c|c|c|}
\hline $\begin{array}{l}\text { Estudos e } \\
\text { Pesquisas em } \\
\text { Teoria Sócio- } \\
\text { Histórica, } \\
\text { Migrações e } \\
\text { Gênero }\end{array}$ & de Almeida & $\begin{array}{l}\text { Católica Dom } \\
\text { Bosco }\end{array}$ & ogrupo/9838267488988970 & \\
\hline $\begin{array}{l}\text { Grupo de } \\
\text { Estudos e } \\
\text { Pesquisas } \\
\text { sobre a } \\
\text { Atividade } \\
\text { Matemática } \\
\text { (GeMAT) }\end{array}$ & $\begin{array}{l}\text { Wellington } \\
\text { Lima Cedro }\end{array}$ & $\begin{array}{l}\text { Universidade } \\
\text { Federal de } \\
\text { Goiás -UFG }\end{array}$ & $\begin{array}{l}\text { http://dgp.cnpq.br/dgp/espelh } \\
\text { ogrupo/0682251886185086 }\end{array}$ & Educação \\
\hline $\begin{array}{l}\text { Infância, } \\
\text { família e } \\
\text { sociedade } \\
\text { (GIFS) }\end{array}$ & $\begin{array}{l}\text { Sônia } \\
\text { Margarida } \\
\text { Gomes Sousa e } \\
\text { Divino de Jesus } \\
\text { da Silva } \\
\text { Rodrigues }\end{array}$ & $\begin{array}{l}\text { Pontifícia } \\
\text { Universidade } \\
\text { Católica de } \\
\text { Goiás - PUC } \\
\text { GOIÁS }\end{array}$ & $\begin{array}{l}\text { http://dgp.cnpq.br/dgp/espelh } \\
\text { ogrupo/8250751483113204 }\end{array}$ & Psicologia \\
\hline INTERFACES & $\begin{array}{l}\text { Não foi possível } \\
\text { localizar o } \\
\text { grupo no DGP } \\
\text { neste momento }\end{array}$ & $\begin{array}{l}\text { Universidade } \\
\text { Federal de } \\
\text { Goiás }\end{array}$ & $\begin{array}{l}\text { Não foi possível localizar o } \\
\text { grupo no DGP neste } \\
\text { momento }\end{array}$ & Educação \\
\hline $\begin{array}{l}\text { Organização do } \\
\text { Ensino na } \\
\text { Perspectiva da } \\
\text { Didática } \\
\text { Desenvolvimen } \\
\text { tal }\end{array}$ & $\begin{array}{l}\text { Marilene } \\
\text { Marzari e } \\
\text { Hidelberto de } \\
\text { Souza Ribeiro }\end{array}$ & $\begin{array}{l}\text { Universidade } \\
\text { Federal de } \\
\text { Mato Grosso - } \\
\text { UFMT }\end{array}$ & $\begin{array}{l}\text { http://dgp.cnpq.br/dgp/espelh } \\
\text { ogrupo/210105 }\end{array}$ & Educação \\
\hline $\begin{array}{l}\text { Teorias da } \\
\text { Educação e } \\
\text { Processos } \\
\text { Pedagógicos }\end{array}$ & $\begin{array}{l}\text { José Carlos } \\
\text { Libâneo e } \\
\text { Raquel } \\
\text { Aparecida } \\
\text { Marra da } \\
\text { Madeira } \\
\text { Freitas }\end{array}$ & $\begin{array}{l}\text { Pontifícia } \\
\text { Universidade } \\
\text { Católica de } \\
\text { Goiás - } \\
\text { PUC/GO }\end{array}$ & $\begin{array}{l}\text { http://dgp.cnpq.br/dgp/espelh } \\
\text { ogrupo/1792 }\end{array}$ & Educação \\
\hline $\begin{array}{l}\text { Trabalho } \\
\text { docente e } \\
\text { educação } \\
\text { escolar- } \\
\text { TRABEDUC }{ }^{17}\end{array}$ & $\begin{array}{l}\text { Marcos } \\
\text { Jerônimo Dias } \\
\text { Júnior e Hugo } \\
\text { Leonardo } \\
\text { Fonseca da } \\
\text { Silva }\end{array}$ & $\begin{array}{l}\text { Universidade } \\
\text { Federal de } \\
\text { Goiás - UFG }\end{array}$ & $\begin{array}{l}\text { http://dgp.cnpq.br/dgp/espelh } \\
\text { ogrupo/3070912585870964 }\end{array}$ & Educação \\
\hline $\begin{array}{l}\text { VIGODSKAIA - } \\
\text { Grupo de } \\
\text { Estudos e } \\
\text { Pesquisas da } \\
\text { Adolescência na } \\
\text { Perspectiva } \\
\text { Histórico- } \\
\text { Cultural }\end{array}$ & $\begin{array}{l}\text { Romy Machado } \\
\text { de Moraes }\end{array}$ & $\begin{array}{l}\text { Universidade } \\
\text { Federal do } \\
\text { Mato Grosso do } \\
\text { Sul - UFMS }\end{array}$ & $\begin{array}{l}\text { http://dgp.cnpq.br/dgp/espelh } \\
\text { ogrupo/7401107951692545 }\end{array}$ & Psicologia \\
\hline
\end{tabular}

${ }^{17}$ Atualmente o grupo chama-se Núcleo de Estudos Educação, Sociedade e Subjetividade - NES. 


\begin{tabular}{|c|c|c|c|c|}
\hline $\begin{array}{l}\text { Nome do grupo } \\
\text { de pesquisa }\end{array}$ & $\begin{array}{l}\text { Líder(es) do } \\
\text { grupo: }\end{array}$ & $\begin{array}{c}\text { Instituição de } \\
\text { origem }\end{array}$ & Espelho do grupo & $\begin{array}{c}\text { Área } \\
\text { predominante }\end{array}$ \\
\hline \multicolumn{5}{|c|}{ REGIÃO NORTE } \\
\hline $\begin{array}{l}\text { Didática da } \\
\text { Resolução de } \\
\text { Problemas em } \\
\text { Ciências e } \\
\text { Matemática }\end{array}$ & $\begin{array}{l}\text { Héctor José } \\
\text { Garcia } \\
\text { Mendoza e } \\
\text { Oscar Tintorer } \\
\text { Delgado }\end{array}$ & $\begin{array}{l}\text { Universidade } \\
\text { Federal de } \\
\text { Roraima - } \\
\text { UFRR }\end{array}$ & $\begin{array}{l}\text { http://dgp.cnpq.br/espelhogru } \\
\text { po/6110202394658012 } \\
\text { Obs.: Link do grupo no DGP } \\
\text { não dá mais acesso ao grupo }\end{array}$ & Educação \\
\hline $\begin{array}{l}\text { Formação de } \\
\text { Professores } \\
\text { com base na } \\
\text { Pedagogia } \\
\text { Histórico- } \\
\text { Crítica }\end{array}$ & $\begin{array}{l}\text { Bruna Ramos } \\
\text { Marinho e } \\
\text { Alessandra } \\
\text { Peternella }\end{array}$ & $\begin{array}{l}\text { Instituto } \\
\text { Federal de } \\
\text { Roraima -IFRR }\end{array}$ & $\begin{array}{l}\text { http://dgp.cnpq.br/espelhogru } \\
\text { po/3663784849244613 } \\
\text { Obs.: Link do grupo no DGP } \\
\text { não dá mais acesso ao grupo }\end{array}$ & Educação \\
\hline $\begin{array}{l}\text { Formação de } \\
\text { Professores em } \\
\text { Psicologia } \\
\text { Histórico- } \\
\text { Cultural e } \\
\text { Pedagogia } \\
\text { Histórico- } \\
\text { Crítica }\end{array}$ & $\begin{array}{l}\text { AlessandraPPet } \\
\text { ernella e Lana } \\
\text { Cristina } \\
\text { Barbosa de } \\
\text { Melo }\end{array}$ & $\begin{array}{l}\text { Universidade } \\
\text { Estadual de } \\
\text { Roraima - } \\
\text { UFRR }\end{array}$ & $\begin{array}{l}\text { http://dgp.cnpq.br/dgp/espelh } \\
\text { ogrupo/0730898043558046 }\end{array}$ & Educação \\
\hline $\begin{array}{l}\text { HISTCULT- } \\
\text { Educação, } \\
\text { Psicologia } \\
\text { Educacional e } \\
\text { Processos } \\
\text { Formativos }\end{array}$ & $\begin{array}{l}\text { Rafael Fonseca } \\
\text { de Castro }\end{array}$ & $\begin{array}{l}\text { Universidade } \\
\text { Federal de } \\
\text { Rondônia - } \\
\text { UNIR }\end{array}$ & $\begin{array}{l}\text { http://dgp.cnpq.br/dgp/espelh } \\
\text { ogrupo/4588784079192347 }\end{array}$ & Educação \\
\hline $\begin{array}{l}\text { GRUPO } \\
\text { AMAZÔNICO } \\
\text { DE ESTUDOS E } \\
\text { PESQUISAS } \\
\text { EM } \\
\text { PSICOLOGIA E } \\
\text { EDUCAÇÃO } \\
\text { (GAEPPE) }\end{array}$ & $\begin{array}{l}\text { Marli Lucia } \\
\text { Tonatto Zibetti } \\
\text { e Juliana da } \\
\text { Silva Nóbrega }\end{array}$ & $\begin{array}{l}\text { Universidade } \\
\text { Federal de } \\
\text { Rondônia - } \\
\text { UNIR }\end{array}$ & $\begin{array}{l}\text { http://dgp.cnpq.br/dgp/espelh } \\
\text { ogrupo/3878565741056715 }\end{array}$ & Psicologia \\
\hline $\begin{array}{l}\text { Grupo de } \\
\text { Estudos e } \\
\text { Pesquisas em } \\
\text { Infância e } \\
\text { Educação } \\
\text { Infantil na } \\
\text { Perspectiva } \\
\text { Histórico- } \\
\text { Cultural - } \\
\text { GEPEHC }\end{array}$ & $\begin{array}{l}\text { Sônia Regina } \\
\text { dos Santos } \\
\text { Teixeira e Ana } \\
\text { Paula de Araújo } \\
\text { Barca }\end{array}$ & $\begin{array}{l}\text { Universidade } \\
\text { Federal do Pará } \\
\text { - UFPA }\end{array}$ & $\begin{array}{l}\text { http://dgp.cnpq.br/dgp/espelh } \\
\text { ogrupo/8139161501771350 }\end{array}$ & Educação \\
\hline $\begin{array}{l}\text { Grupo de } \\
\text { estudos em } \\
\text { Letramento e } \\
\text { Numeramento } \\
\text { (GELEN) }\end{array}$ & $\begin{array}{l}\text { Rosimeire } \\
\text { Aparecida } \\
\text { Rodrigues e } \\
\text { Adriana Demite } \\
\text { Stephani }\end{array}$ & $\begin{array}{l}\text { Universidade } \\
\text { Federal do } \\
\text { Tocantins - } \\
\text { UFT }\end{array}$ & $\begin{array}{l}\text { http://dgp.cnpq.br/dgp/espelh } \\
\text { ogrupo/6230506969688514 }\end{array}$ & Educação \\
\hline $\begin{array}{l}\text { Povos } \\
\text { Indígenas, } \\
\text { Populações } \\
\text { Amazônicas e } \\
\text { Estudos } \\
\text { Transdisciplina } \\
\text { res }\end{array}$ & Maxim Repetto & $\begin{array}{l}\text { Universidade } \\
\text { Federal de } \\
\text { Roraima }\end{array}$ & $\begin{array}{l}\text { http://dgp.cnpq.br/dgp/espelh } \\
\text { ogrupo/7719344405699095 }\end{array}$ & Educação \\
\hline Psicologia e & Juliana Chioca & Universidade & http://dgp.cnpq.br/dgp/espelh & Psicologia \\
\hline
\end{tabular}




\begin{tabular}{|c|c|c|c|c|}
\hline $\begin{array}{l}\text { Educação: } \\
\text { contribuições à } \\
\text { Psicologia } \\
\text { Histórico- } \\
\text { cultural }\end{array}$ & $\begin{array}{l}\text { Ipolito e } \\
\text { Gustavo Cunha } \\
\text { de Araújo }\end{array}$ & $\begin{array}{l}\text { Federal do } \\
\text { Tocantins - } \\
\text { UFT }\end{array}$ & ogrupo/0638951842366885 & \\
\hline $\begin{array}{l}\text { Rede } \\
\text { Laboratórios } \\
\text { Socionaturais } \\
\text { Vivos e os } \\
\text { Conhecimentos } \\
\text { Tradicionais na } \\
\text { Amazônia e na } \\
\text { América Latina }\end{array}$ & Maxim Repetto & $\begin{array}{l}\text { Universidade } \\
\text { Federal de } \\
\text { Roraima - } \\
\text { UFRR }\end{array}$ & $\begin{array}{l}\text { http://dgp.cnpq.br/dgp/espelh } \\
\text { ogrupo/0310137226775512 }\end{array}$ & Antropologia \\
\hline $\begin{array}{l}\text { Teoria } \\
\text { histórico- } \\
\text { cultural, } \\
\text { infância e } \\
\text { pedagogia }\end{array}$ & $\begin{array}{l}\text { Michelle de } \\
\text { Freitas Bissoli }\end{array}$ & $\begin{array}{l}\text { Universidade } \\
\text { Federal do } \\
\text { Amazonas - } \\
\text { UFAM }\end{array}$ & $\begin{array}{l}\text { http://dgp.cnpq.br/dgp/espelh } \\
\text { ogrupo/10814 }\end{array}$ & Educação \\
\hline
\end{tabular}

\section{Referências}

ASBAHR, F.S.F. A psicologia histórico-cultural na pesquisa brasileira. In: Anais do XIV Congresso Brasileiro de Psicologia Escolar e Educacional. Abrapee:

Campo Grande, 2019. ISSN 1981-2566 (Resumo). Disponível em http://www2.pol.org.br/inscricoesonline/conpe/2019/anais/detalhe.cfm?id=10141.

CLEMENTE, J. Políticas e pesquisas em educação especial: das diretrizes para a América Latina ao mapeamento dos grupos de pesquisa no Brasil [Dissertação em elaboração]. Universidade Estadual de Maringá, 2020.

CONSELHO NACIONAL DE DESENVOLVIMENTO CIENTÍFICO E TECNOLÓGICO - CNPq. Diretório dos grupos de pesquisa no Brasil. http://lattes.cnpq.br/web/dgp.

FERREIRA, N.S. A.. As pesquisas denominadas "estado da arte". Educ. Soc., Campinas, v. 23, n. 79, p. 257-272, ago. 2002. Disponível em http://www.scielo.br/scielo.php?script=sci_arttext\&pid=S0101-

73302002000300013\&lng=pt\&nrm=iso. Acessos em 17 fev. 2016 DOI: https://doi.org/10.1590/S0101-73302002000300013.

GUARAGNA, C. S.. Estado da arte das produções brasileiras sobre orientação à queixa escolar a partir da psicologia histórico-cultural. Relatório de Iniciação Científica (Fapesp), 2020.

OLIVEIRA, M. L. S. A. \& ASBAHR, F. S. F.. Psicologia histórico-cultural e o processo de saúde-doença na pesquisa brasileira. Anais XXVI Semana e XIII Congresso de Psicologia da Unesp Bauru, 2019. 
SANTOS, M. A. Princípios histórico-culturais para a organização de formações docentes continuadas concretas [Dissertação de Mestrado não publicada]. Universidade Estadual Paulista "Júlio de Mesquita Filho", Bauru, 2020. http:/hdl.handle.net/11449/191842.

SILVA, A. O.. Líderes dos Grupos de Pesquisa do Diretório do CNPq sobre a Teoria Histórico-Cultural no Brasil: cenários e desafios sobre as políticas públicas. Relatório parcial de Iniciação Científica (CNPq), 2021.

TOASSA, G.; ASBAHR, F.S.F.; SOUZA, M.P.R. The Golden Age of Soviet Psychology in the mirror of contemporary Marxian psychology in Brazil. Yasnisky, Anton (org). A History of Marxist Psychology: The Golden Age of Soviet Science. New York: Routledge, 2020, p. 131-155. 